\title{
A systematic review and meta-analysis indicates long-term risk of chronic and end-stage kidney disease after preeclampsia
}

\author{
Bianca Covella ${ }^{1}$, Angela Elena Vinturache ${ }^{2}$, Gianfranca Cabiddu ${ }^{3}$, Rossella Attini ${ }^{4}$, Loreto Gesualdo ${ }^{1}$, \\ Elisabetta Versino ${ }^{5}$ and Giorgina Barbara Piccoli ${ }^{5}$
}

${ }^{1}$ Department of Medicine, Unit of Nephrology, Dialysis and Transplantation, Polyclinic University Hospital, Bari, Italy; ${ }^{2}$ Department of Obstetrics and Gynaecology Women's Centre, John Radcliffe Hospital, Oxford University Hospitals NHS Foundation Trust, Oxford, UK; ${ }^{3}$ Department of Medicine, Nephrology Ospedale Botzu, Cagliari, Italy; ${ }^{4}$ Department of Surgery, Obstetrics, University of Torino, Torino, Italy; and ${ }^{5}$ Department of Clinical and Biological Sciences, University of Torino, Torino, Italy

Preeclampsia is a pregnancy-related syndrome of variable severity, classically characterized by acute kidney involvement, with hypertension and/or proteinuria and reduced kidney function. Once considered a self-limited disease healed by delivery, it is now acknowledged that preeclampsia can affect cardiovascular and kidney health in the long term. The entity of risk has not been established and consequently follow-up policies have not been defined. Here we undertook a systematic review to gain better insights into the need for post-preeclampsia followup. Articles published between January 2000 and March 2018 were selected, dealing with at least 20 preeclampsia patients, with follow-up of 4 years or more (MEDLINE, Embase, and Cochrane Library). No quality selection or language restriction was performed. Of the 10,510 titles and abstracts originally considered, 21 papers were selected, providing information on 110,803 cases with and $2,680,929$ controls without preeclampsia, with partial overlap between studies on the same databases. Heterogeneity was high, and a random meta-analytic model selected. The increase in risk of end stage renal disease after preeclampsia was significant (meta-analytic risk ratios (95\% confidence interval) 6.35 (2.73-14.79)); the risk of albuminuria and chronic kidney disease increased but statistical significance was not reached (4.31 (0.9519.58) and 2.03 (0.58-7.32), respectively). Translating meta-analytic risk into the number of patients who need follow-up to detect one adverse event, 310 patients with preeclampsia are needed to identify one woman with end stage renal disease or four to identify one woman with albuminuria. Heterogeneity in definitions, insufficient follow-up and incomplete recruitment may account for discrepancies. Thus, preeclampsia significantly increases the risk of end stage renal disease. However, there is lack of

Correspondence: Giorgina Barbara Piccoli, Department of Clinical and Biological Sciences, University of Torino, Torino, Italy or Ospedale san Luigi Gonzaga, Regione Gonzole, Orbassano Torino 10100, Italy; and Centre Hospitalier Le Mans, Le Mans 72000 France. E-mail: gbpiccoli@yahoo.it

Received 13 December 2018; revised 23 March 2019; accepted 28 March 2019; published online 14 May 2019 sufficient data to show a relationship between preeclampsia, albuminuria and chronic kidney disease, underlining the need for further prospective studies.

Kidney International (2019) घ, घ-目; https://doi.org/10.1016/ j.kint.2019.03.033

KEYWORDS: albuminuria; chronic kidney disease; dialysis; eGFR; hypertensive disorders of pregnancy; preeclampsia; rapid review; systematic review Copyright ( ) 2019, International Society of Nephrology. Published by Elsevier Inc. All rights reserved.

reeclampsia $(\mathrm{PE})$ is a pregnancy-related syndrome of variable severity that has been differently defined, pointing to hypertension, fetal growth, and kidney involvement. ${ }^{1-3}$ Although the presence of proteinuria, which was long seen as a requisite for diagnosis, is no longer considered to be a condition sine qua non, an increase in serum creatinine is presently considered an alternative diagnostic element, thus further pointing to the central role of the kidney in this syndrome. $^{1-12} P E$ has in fact been defined as a transitory reversible kidney disease that resolves spontaneously after delivery. In the classical definition of $\mathrm{PE}$, kidney derangements are reversible within 1 to 3 months of delivery, regardless of their severity; however, this may not be the case in all patients, and the relationship between $\mathrm{PE}$ and chronic kidney disease (CKD) is not entirely understood. ${ }^{13-18}$

The prevalence of $\mathrm{PE}$ has been variously estimated: the range most frequently reported is $3 \%$ to $5 \%$, but may decrease to $1 \%$ to $2 \%$ in "low-risk pregnancies" or increase to $>10 \%$ if related disorders such as pregnancy-induced hypertension and hemolysis, elevated liver enzymes, low platelet (HELLP) syndrome are included within the broad definition of "the hypertensive disorders of pregnancy." The non-univocal definition of superimposed PE, identifying cases in which the clinical syndrome of hypertension and proteinuria develops in the presence of preexisting hypertension or kidney disease, adds to the difficulty in reaching univocal definitions. ${ }^{1-4,18-23}$ The discussion on whether PE is a single disease, a syndrome, or a spectrum of alterations is still open; the new molecular approaches, and in particular the analysis of the ratio between proangiogenic and anti-angiogenic factors, such as placental growth factor and soluble fms-like tyrosine kinase 1, may offer some interesting insights into its pathogenesis. ${ }^{1-4,21-30}$ 
PE is no longer considered as a transitory disease and has been associated with a vast array of cardiovascular and renal diseases, of which the pregnancy-related affection may be a herald, a cause, or a consequence. ${ }^{31-36}$ Most of the studies and virtually all the systematic reviews show that patients who had PE in $\geq 1$ pregnancy are at an increased risk of developing cardiovascular and metabolic diseases. ${ }^{31-41}$ However, the entity of the risk, the timing of the development of clinical problems, and the control strategies that can be used are not clear, and large prospective cohort studies are still lacking.

This uncertainty is shared by the analysis of the risk of CKD (including end-stage renal disease [ESRD]), which may become clinically evident only in the long term and whose global prevalence remains low, possibly too low to justify specific follow-up programs. A comprehensive systematic review focused on kidney disease, performed in 2010, highlighted the association between microalbuminuria (but not estimated glomerular filtration rate [eGFR]) and a previous episode of PE. ${ }^{42}$ The review includes 7 studies reporting on outcomes recorded at least 6 weeks postpartum $(\sim 300 \mathrm{PE}$ episodes). Several large studies were published after this review appeared, and information is also accumulating on hard outcomes, such as ESRD.

It was in this context that we decided to undertake the present systematic review to gather updated information from large recent observational and cohort studies focused on the long-term occurrence of ESRD, CKD (defined on the basis of glomerular filtration rate [GFR] and presence of proteinuria), and morbidity from kidney-related causes after an episode of $\mathrm{PE}$ as a guide for defining long-term control and CKD prevention strategies.

\section{RESULTS}

\section{Characteristics of the studies}

After removing duplicates, 8366 titles and abstracts were screened and the full texts of 159 articles were assessed, leading to a final selection of 21 articles for qualitative synthesis and 11 included in the different meta-analyses (Figure 1). ${ }^{43-63}$

Overall, qualitative data provided information on 110,803 cases and 2,680,929 controls, with a partial overlap between studies in the same databases (Table 1).

Selected studies were heterogeneous in terms of number of cases (30-26,651), setting of the study, over half being from European countries, period of pregnancy, and duration of follow-up (Table 1).

None of the studies were prospective; the interval between pregnancy and analysis ranged from 4.4 to $>30$ years. The definition of exposure (PE alone or combined with other hypertensive disorders of pregnancy) and the definitions of the outcomes and their measures were not homogeneous,

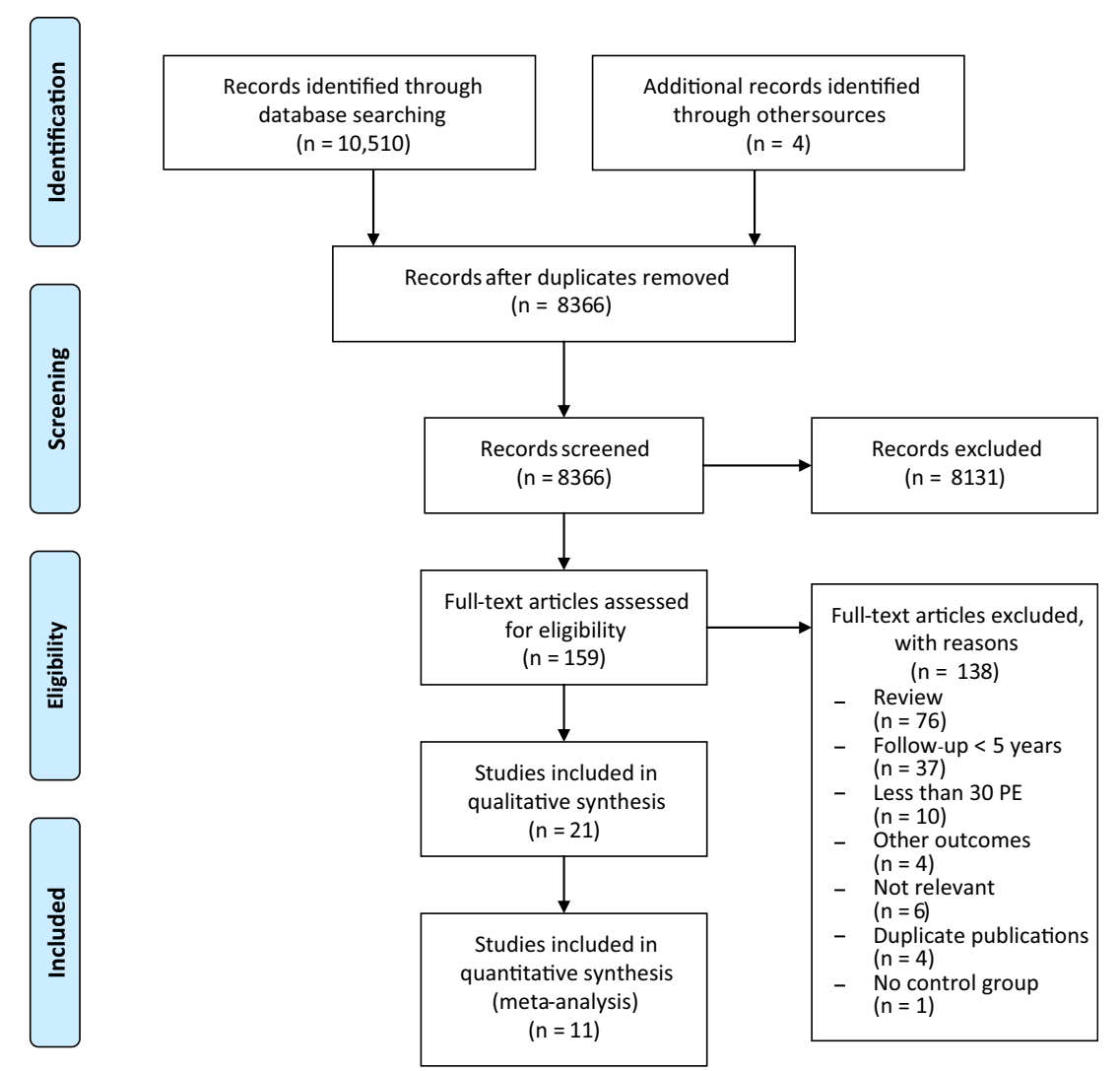

Figure 1 | Preferred Reporting Items for Systematic Reviews and Meta-Analyses flowchart of study selection and database search. PE, preeclampsia. Reprinted with permission from Moher D, Liberati A, Tetzlaff J, Altman DG; PRISMA Group. Preferred Reporting Items for Systematic Reviews and Meta-analyses: the PRISMA statement. PLoS Med. 2009;6:e1000097. Copyright (C) 2009 Moher et al. 
following also the changes that have occurred over time in the nomenclature of these diseases (Tables $2^{64}$ and 3 ).

There were 2 main types of study design: cross-sectional evaluation of a cohort of patients retrospectively identified (8 studies) and linkage between different databases (11 studies). Two studies analyzed selected patients using questionnaires administered in the setting of a randomized controlled trial for other purposes (Table 2).

Four main outcomes were examined, alone or in combination: development of ESRD (Table 4), GFR level or presence of CKD (Table 5), development of proteinuria or microalbuminuria (Table 5), and hospitalization for causes related to CKD (Supplementary Tables S1 and S2). Four studies examined different outcomes, alone or in combination (1 examined hemodynamic pattern, 1 looked at mortality caused by CKD, and 1 investigated outcomes associated with kidney biopsy) (Supplementary Table S1).

Although ESRD and hospitalization were dichotomous in all articles, kidney function was analyzed in 7 articles as a dichotomous variable (CKD vs. normal kidney function or hyperfiltration vs. normal kidney function) and in 7 articles as continuous eGFR values by using different formulas (Modification of Diet in Renal Disease study equation, Chronic Kidney Disease Epidemiology Collaboration equation, and creatinine-cystatin equation; Table 5). Likewise, the presence of albuminuria was analyzed as a continuous covariate in 4 articles, according to a threshold in 7 articles and in both ways in 2 studies (Table 5). The modalities were however different and included 24-hour urine collections and/or albumin/creatinine ratio (Tables 3 and 5).

The studies selected reported on a consistent proportion of the exposed population; completeness of selection was higher in linkage databases and in studies based on questionnaires; completeness was consistently lower in cross-sectional analyses of populations selected on the basis of pregnancy data recorded 4 to 30 years previously, the range going from $20 \%$ to $100 \%$ (Supplementary Table S3A-C).

\section{Quality of the studies, heterogeneity, and publication bias}

The evidence was rated as of overall low quality by the Grading of Recommendations Assessment, Development and Evaluation (GRADE) scale because of the observational nature of the studies; however, studies were rated as of fair to good quality in the National Institutes of Health scale, which is focused on observational studies (Supplementary Tables S4 and S5). This discrepancy is due to the fact that the GRADE scale is focused on the absolute value of the evidence whereas the National Institutes of Health scale considers the specific limitations of each study in the framework of their intrinsic limitations.

Indeed, even if the National Institutes of Health scale is considered, no study was fully unbiased, as was to be expected given the retrospective nature of the analyses. Clinical heterogeneity was high.

Statistical heterogeneity was also high: for the outcome ESRD, the study by Wang et al. accounted for most of heterogeneity, with $\mathrm{I}^{2}$ decreasing from $94 \%$ to $23 \%{ }^{53}$ For CKD, the studies by Wang et al..$^{53}$ and Ayansina et al. ${ }^{48}$ contributed to most of heterogeneity, with $\mathrm{I}^{2}$ decreasing from $98 \%$ to $60 \%$. The study by Paauw et al. contributed to most of heterogeneity of GFR, with $\mathrm{I}^{2}$ decreasing from $83 \%$ to $73 \%{ }^{43}$ For albuminuria, the study by McDonald et al. contributed to virtually all heterogeneity, ${ }^{55}$ and for hospitalization, the study by Kessous et al. contributed to most of heterogeneity, with $\mathrm{I}^{2}$ decreasing from $85 \%$ to $44 \%{ }^{49}$

The funnel plot analysis reveals a substantial symmetry for ESRD and eGFR, suggesting the absence of publication bias. For the outcomes CKD and hospitalization, a gap in bottom corners of the graphs suggest that small nonsignificant studies had been omitted in both directions, balancing the effect estimate. For albuminuria, a gap in the bottom left corner of the graph suggests that a protective effect of $\mathrm{PE}$ was omitted, leading to a possible mild overestimation of the effect of PE (funnel plots are shown in Supplementary Figures S1-S5).

\section{Descriptive analysis: risk of ESRD}

The definition of outcomes was homogeneous only for ESRD, whose incidence was recorded over time, leading to the construction of specific, albeit differently built curves: eventfree in the articles from Taiwan ${ }^{50,53}$ and incidence in the articles from Norway ${ }^{54,58-60}$ (Table 4). It should be noted that the curves of patients with or without PE start differentiating from the fourth year of observation in Norway and from the beginning of the observation in Taiwan; in both cases the differences are statistically significant. None of the studies adjust for predialysis mortality, a potential attrition bias, because of the higher mortality in patients with CKD than in the overall population.

\section{Descriptive analysis: risk of CKD and proteinuria}

The development of CKD was analyzed in different waysdichotomized at eGFR of $60 \mathrm{ml} / \mathrm{min}$ per $1.73 \mathrm{~m}^{2}$ or eGFR as a continuous variable - by using different formulas (Modification of Diet in Renal Disease study equation and Chronic Kidney Disease Epidemiology Collaboration equation) and different tests, as reported in Table 3. No significant difference in eGFR was observed, but the difference (increase in CKD after PE) is significant in the dichotomous analysis in most single studies (Table 5).

A similar pattern is observed in the case of protein excretion, expressed as microalbuminuria, as well as protein/ creatinine ratio (Table 5).

Correction for dialysis initiation was attempted in 1 article (no case recorded), ${ }^{43}$ while none reported adjustment for mortality, possibly because of the rarity of this event in young women. The overall prevalence of CKD in the meta-analyzed control populations, excluding the 2 articles whose outcome was hyperfiltration, was low (1508 events per 234,068 controls [0.64\%]).

Other outcomes include mortality, hospitalization, and need for kidney biopsy (Supplementary Tables S1 and S2; meta-analysis shown in Supplementary Figure S6). 


\begin{tabular}{|c|c|c|c|c|c|c|c|c|}
\hline Study & Country & $\begin{array}{l}\text { Period of } \\
\text { pregnancy }\end{array}$ & $\begin{array}{l}\text { Period of } \\
\text { study }\end{array}$ & Design & $\begin{array}{l}\text { Exposed } / \text { not } \\
\text { exposed }\end{array}$ & $\begin{array}{l}\text { Aim of the study } \\
\text { (as reported in the article) }\end{array}$ & $\begin{array}{l}\text { Duration of } \\
\text { follow-up after } \\
\text { pregnancy (yr) }\end{array}$ & $\begin{array}{l}\text { Renal outcome(s) } \\
\text { (other outcomes) }\end{array}$ \\
\hline Paauw et al. ${ }^{43}$ & $\mathrm{NL}$ & 1997-1998 & 1997-2012 & $\begin{array}{l}\text { Cohort study } \\
\text { (PREVEND study); } \\
\text { linkage with the ESRD } \\
\text { registry }\end{array}$ & $977 / 1805$ & $\begin{array}{l}\text { To evaluate the incidence of } \\
\text { CKD and ESRD and the course } \\
\text { of kidney function after a } \\
\text { hypertensive disorder of } \\
\text { pregnancy in a longitudinal } \\
\text { setting }\end{array}$ & 11 & $\begin{array}{l}\text { CKD, ESRD, } \\
\text { albuminuria }\end{array}$ \\
\hline $\begin{array}{l}\text { Lopes van Balen } \\
\quad \text { et al. }{ }^{44}\end{array}$ & NL & NA & Until 2011 & $\begin{array}{l}\text { Retrospective cohort, } \\
\text { cross-sectional } \\
\text { evaluation }\end{array}$ & $79 / 49$ & $\begin{array}{l}\text { To test the hypothesis that in } \\
\text { women with a history of } P E \text {, } \\
\text { kidney function correlates } \\
\text { with endothelium-dependent } \\
\text { flow-mediated vasodilation }\end{array}$ & 4.4 & $\begin{array}{l}\text { CKD, microalbuminuria, } \\
(\text { FMD) }\end{array}$ \\
\hline Tooher et al. ${ }^{45}$ & $\mathrm{AU}$ & 1980-1989 & NA & $\begin{array}{l}\text { Retrospective record } \\
\text { linkage }\end{array}$ & $\begin{array}{c}1158(1364 \\
\text { pregnant)/27,262 }\end{array}$ & $\begin{array}{l}\text { To examine whether the } \\
\text { hypertensive disorders of } \\
\text { pregnancy affect women's } \\
\text { future cardiovascular health }\end{array}$ & $20(3-29)$ & $\begin{array}{c}\text { Hospitalization for } \\
\text { CKD (separately: HT, CVD, } \\
\text { stroke) }\end{array}$ \\
\hline Bokslag et al. ${ }^{46}$ & NL & 1998-2005 & 2014-2016 & $\begin{array}{l}\text { Retrospective cohort, } \\
\text { cross-sectional } \\
\text { evaluation }\end{array}$ & $131 / 56$ & $\begin{array}{l}\text { To assess cardiovascular risk } \\
\text { factors and established } \\
\text { cardiovascular disease in } \\
\text { women after early-onset } P E \text {, in } \\
\text { the fifth decade of life }\end{array}$ & $13.1 \pm 2.2$ & CKD, microalbuminuria \\
\hline Paauw et al. ${ }^{47}$ & NL & $1991-2007$ & 2009-2010 & $\begin{array}{c}\text { Cohort study (PREVFEM } \\
\text { study); cross- sectional } \\
\text { evaluation }\end{array}$ & $339 / 332$ & $\begin{array}{l}\text { To study renal function in a } \\
\text { large cohort of well- } \\
\text { characterized women with } \\
\text { previous early-onset } P E, 10 \mathrm{yr} \\
\text { postpartum }\end{array}$ & $9.1 \pm 3.7$ & CKD, proteinuria \\
\hline Ayansina et al. ${ }^{48}$ & GB-SCT & $1950-2008$ & 2009 & $\begin{array}{l}\text { Retrospective record } \\
\text { linkage }\end{array}$ & $811^{\mathrm{a}} / 10,457$ & $\begin{array}{l}\text { To assess the long-term } \\
\text { effects of the hypertensive } \\
\text { disorders of pregnancy on } \\
\text { kidney function by using a } \\
\text { population-based cohort, } \\
\text { adjusting for confounders }\end{array}$ & $>15$ & $\begin{array}{l}\text { CKD, hospitalization } \\
\text { for CKD }\end{array}$ \\
\hline Kessous et al. ${ }^{49}$ & IL & 1988-2012 & 2012 & $\begin{array}{l}\text { Retrospective record } \\
\text { linkage }\end{array}$ & $7824 / 88,546$ & $\begin{array}{l}\text { To investigate whether severe } \\
\text { and recurrent } P E \text { increase the } \\
\text { risk for long-term } \\
\text { atherosclerotic morbidity } \\
\text { (cardiovascular and renal) }\end{array}$ & 11.2 & $\begin{array}{l}\text { CKD, hospitalization } \\
\text { for CVD }\end{array}$ \\
\hline Wu et al..$^{50}$ & TW & 1998-2002 & NC & $\begin{array}{l}\text { Retrospective cohort } \\
\quad \text { (registry data) }\end{array}$ & $13,633 / 930,841$ & $\begin{array}{l}\text { To determine the long-term } \\
\text { postpartum risk of ESRD in } \\
\text { women with hypertensive } \\
\text { disorders in pregnancy }\end{array}$ & $9(7.79-10.02)$ & ESRD \\
\hline Sandvik et al..$^{51}$ & NO & 1998-2000 & 2009-2010 & $\begin{array}{l}\text { Retrospective cohort, } \\
\text { cross-sectional } \\
\text { evaluation }\end{array}$ & $89 / 69$ & $\begin{array}{l}\text { To investigate the occurrence } \\
\text { of the early stages of CKD after } \\
\text { a single } P E \text { pregnancy }\end{array}$ & $10.9 \pm 1$ & CKD, microalbuminuria \\
\hline
\end{tabular}




\begin{tabular}{|c|c|c|c|c|c|c|c|c|}
\hline Männistö et al. ${ }^{52}$ & $\mathrm{FI}$ & 1966 & $1967-2008^{b}$ & $\begin{array}{l}\text { Retrospective record } \\
\text { linkage }\end{array}$ & $242 / 6552$ & $\begin{array}{l}\text { To evaluate the long-term risk } \\
\text { in women for subsequent } \\
\text { cardiovascular, } \\
\text { cerebrovascular, and CKD as } \\
\text { well as CVD mortality } \\
\text { associated with the full } \\
\text { spectrum of hypertensive } \\
\text { disorders during pregnancy }\end{array}$ & $39.4(3.0-43.6)$ & $\begin{array}{c}\text { CKD (CVD, } \\
\text { cerebrovascular disease, } \\
\text { diabetes, HT) }\end{array}$ \\
\hline Wang et al. ${ }^{53}$ & TW & $\begin{array}{c}1996-2009 \text { or } \\
1998-2009\end{array}$ & 2009 & $\begin{array}{l}\text { Retrospective record } \\
\text { linkage }\end{array}$ & $17,998^{\mathrm{C}} / 213,397$ & $\begin{array}{l}\text { To investigate the risk of ESRD } \\
\text { among Taiwanese women } \\
\text { who had a hypertensive } \\
\text { disorder during pregnancy }\end{array}$ & 6.3 & CKD, ESRD \\
\hline Vikse et al. ${ }^{54}$ & NO & 1967-2008 & 2009 & $\begin{array}{l}\text { Retrospective record } \\
\text { linkage }\end{array}$ & $\begin{array}{l}\text { First pregnancy: } \\
\text { 25,821/544,854 } \\
\text { Second pregnancy: } \\
8977 / 27,7233\end{array}$ & $\begin{array}{l}\text { To assess the role of genetic } \\
\text { and environmental } \\
\text { contributions to the } \\
\text { association between } P E \text { and } \\
\text { ESRD, investigating the } \\
\text { occurrence of ESRD in } \\
\text { relatives of women with PE in } \\
\text { their first pregnancy }\end{array}$ & $19.6 \pm 10.4$ & ESRD \\
\hline McDonald et al. ${ }^{55}$ & International & NA & 2003-2005 & $\begin{array}{l}\text { Recall questionnaires, } \\
\text { cross-sectional } \\
\text { evaluation in RCT } \\
\text { (ORIGIN trial) }\end{array}$ & $467^{d} / 3613$ & $\begin{array}{l}\text { To explore the relationship } \\
\text { between } P E \text { (severe and } \\
\text { nonsevere) and CVD } \\
\text { after accounting for } \\
\text { albuminuria and other } \\
\text { known cardiovascular } \\
\text { risk factors }\end{array}$ & $N A^{e}$ & $\begin{array}{l}\text { CKD, microalbuminuria } \\
\text { (CVD) }\end{array}$ \\
\hline $\begin{array}{l}\text { Bhattacharya } \\
\text { et al. }\end{array}$ & GB-SCT & $\begin{array}{l}\text { Database } \\
\text { started in } \\
1950\end{array}$ & 2007 & $\begin{array}{l}\text { Retrospective record } \\
\text { linkage }\end{array}$ & $2026^{f} / 23,937$ & $\begin{array}{l}\text { To examine the relationship } \\
\text { between the hypertensive } \\
\text { disorders of pregnancy and } \\
\text { future hospital admittance for } \\
\text { selected conditions, cancer, } \\
\text { and death }\end{array}$ & $>30$ & $\begin{array}{c}\text { Mortality and } \\
\text { hospitalization for CKD }\end{array}$ \\
\hline $\begin{array}{l}\text { Shahbazian } \\
\text { et al. }\end{array}$ & IR & 2001-2003 & NA & $\begin{array}{l}\text { Retrospective cohort, } \\
\text { cross- sectional } \\
\text { evaluation }\end{array}$ & $35 / 35$ & $\begin{array}{l}\text { To assess whether women } \\
\text { with a history of } P E \text { had higher } \\
\text { rates of hypertension and } \\
\text { microalbuminuria compared } \\
\text { with women with uneventful } \\
\text { pregnancy }\end{array}$ & $5.7(5.2-7.3)$ & $\begin{array}{c}\text { CKD, microalbuminuria } \\
(\mathrm{HT})\end{array}$ \\
\hline Vikse et $a .^{58}$ & NO & 1988-2005 & 2005 & $\begin{array}{l}\text { Retrospective record } \\
\text { linkage }\end{array}$ & $60 / 522$ & $\begin{array}{c}\text { To investigate whether PE and } \\
\text { other adverse pregnancy } \\
\text { outcomes were associated } \\
\text { with late renal damage and } \\
\text { increased risk of progression } \\
\text { of established CKD }\end{array}$ & $\begin{array}{l}\text { Up to } 16 \text { after } \\
\text { biopsy; age at first } \\
\text { pregnancy, } 24 \pm \\
8.4 \text {; age at biopsy, } \\
41.3 \pm 4.8\end{array}$ & ESRD \\
\hline Sandvik et al. ${ }^{59}$ & NO & 1967-1994 & $\begin{array}{l}2004 \text { or } \\
2005^{\text {b }}\end{array}$ & $\begin{array}{l}\text { Retrospective record } \\
\text { linkage }\end{array}$ & $216 / 1265$ & $\begin{array}{l}\text { To assess the extent to which } \\
\text { adverse pregnancy outcomes } \\
\text { were associated with later } \\
\text { development of ESRD or } \\
\text { premature death in women } \\
\text { with diabetes }\end{array}$ & Up to 37 & ESRD (death) \\
\hline
\end{tabular}




\begin{tabular}{|c|c|c|c|c|c|c|c|c|}
\hline Study & Country & $\begin{array}{l}\text { Period of } \\
\text { pregnancy }\end{array}$ & $\begin{array}{l}\text { Period of } \\
\text { study }\end{array}$ & Design & $\begin{array}{l}\text { Exposed } / \text { not } \\
\text { exposed }\end{array}$ & $\begin{array}{l}\text { Aim of the study } \\
\text { (as reported in the article) }\end{array}$ & $\begin{array}{l}\text { Duration of } \\
\text { follow-up after } \\
\text { pregnancy (yr) }\end{array}$ & $\begin{array}{l}\text { Renal outcome(s) } \\
\text { (other outcomes) }\end{array}$ \\
\hline Vikse et al. ${ }^{60}$ & NO & 1967-1991 & 2004 & $\begin{array}{l}\text { Retrospective record } \\
\text { linkage }\end{array}$ & $20,918 / 549,515$ & $\begin{array}{l}\text { To assess the association } \\
\text { between } P E \text { in } \geq 1 \text { pregnancy } \\
\text { and the development of ESRD }\end{array}$ & $\begin{array}{l}26.5 \pm 7.5 \text { after the } \\
\text { first pregnancy }\end{array}$ & ESRD \\
\hline Lampinen et al. ${ }^{61}$ & $\mathrm{FI}$ & 1996-1998 & NA & $\begin{array}{l}\text { Retrospective cohort, } \\
\text { cross-sectional } \\
\text { evaluation }\end{array}$ & $30 / 21$ & $\begin{array}{l}\text { To assess whether the degree } \\
\text { of proteinuria in severe } P E \text { is } \\
\text { related to impairment of } \\
\text { vascular dilatation and/or } \\
\text { kidney function years after } \\
\text { pregnancy }\end{array}$ & $5-6$ & $\begin{array}{l}\text { CKD, microalbuminuria } \\
\text { (FBF) }\end{array}$ \\
\hline Vikse et al. ${ }^{62}$ & NO & 1967-1998 & 2002 & $\begin{array}{l}\text { Retrospective record } \\
\text { linkage }\end{array}$ & $29,317 / 72,7103$ & $\begin{array}{l}\text { To assess whether perinatal } \\
\text { outcomes are associated with } \\
\text { later clinical CKD diagnosed } \\
\text { by kidney biopsy }\end{array}$ & $15.9 \pm 9.4$ & Kidney biopsy \\
\hline Shammas et al. ${ }^{63}$ & JO & 1988 & $10 \mathrm{yr}$ later & $\begin{array}{l}\text { Retrospective cohort, } \\
\text { cross-sectional } \\
\text { evaluation }\end{array}$ & $47^{9} / 46$ & $\begin{array}{l}\text { To assess the development of } \\
\text { hypertension and its relation } \\
\text { to renal function } 10 \mathrm{yr} \text { after a } \\
\text { pregnancy complicated by } P E \\
\text { or PIH }\end{array}$ & 10 & $\begin{array}{c}\text { CKD, microalbuminuria } \\
(\mathrm{HT})\end{array}$ \\
\hline
\end{tabular}

AU, Australia; CKD, chronic kidney disease; CVD, cardiovascular disease; ESRD, end-stage renal disease; FBF, forearm blood flow; FI, Finland; FMD, flow-mediated dilatation; GB-SCT, Great Britain-Scotland; GH, gestational hypertension; HDP, hypertensive disorders of pregnancy; HT, hypertension; IL, Israel; IR, Iran; JO, Jordan; NA, not available; NC, not clear; NL, The Netherlands; NO, Norway; ORIGIN, Outcome Reduction with an Initial Glargine Intervention; PE, preeclampsia; PIH, pregnancy-induced hypertension; PREVEND, Prevention of Renal and Vascular End-stage Disease; PREVFEM, Preeclampsia Risk EValuation in FEMales; RCT, randomized controlled trial; TW, Taiwan.

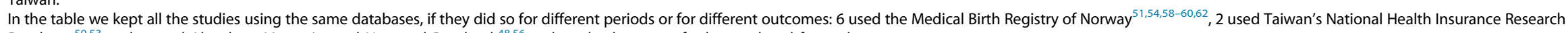
Database, ${ }^{50,53}$ and 2 used Aberdeen Maternity and Neonatal Databank ${ }^{48,56}$; only 1 database was further analyzed for each outcome.

aAyansina et al: Women with GH are not considered in our study (women with GH: 3583).

bDifferent databases.

'Wang et al:: Women with HDP other than PE are not considered in our study (women with HDP: 26,651).

${ }^{\mathrm{d}} \mathrm{McD}$ onald et al: 108 severe preeclampsia and 359 nonsevere preeclampsia.

${ }^{\mathrm{e}} \mathrm{McD}$ Donald et al.: Follow-up $>20 \mathrm{yr}$ on the basis of study design.

'Bhattacharya et al: Women with GH are not considered in our study (women with GH: 8891).

${ }^{9}$ Shammas et al.: Women with GH are not considered in our study (women with GH: 54). 
Table 2 | Main definitions of exposure in the articles reviewed as well as the source of definition of PE

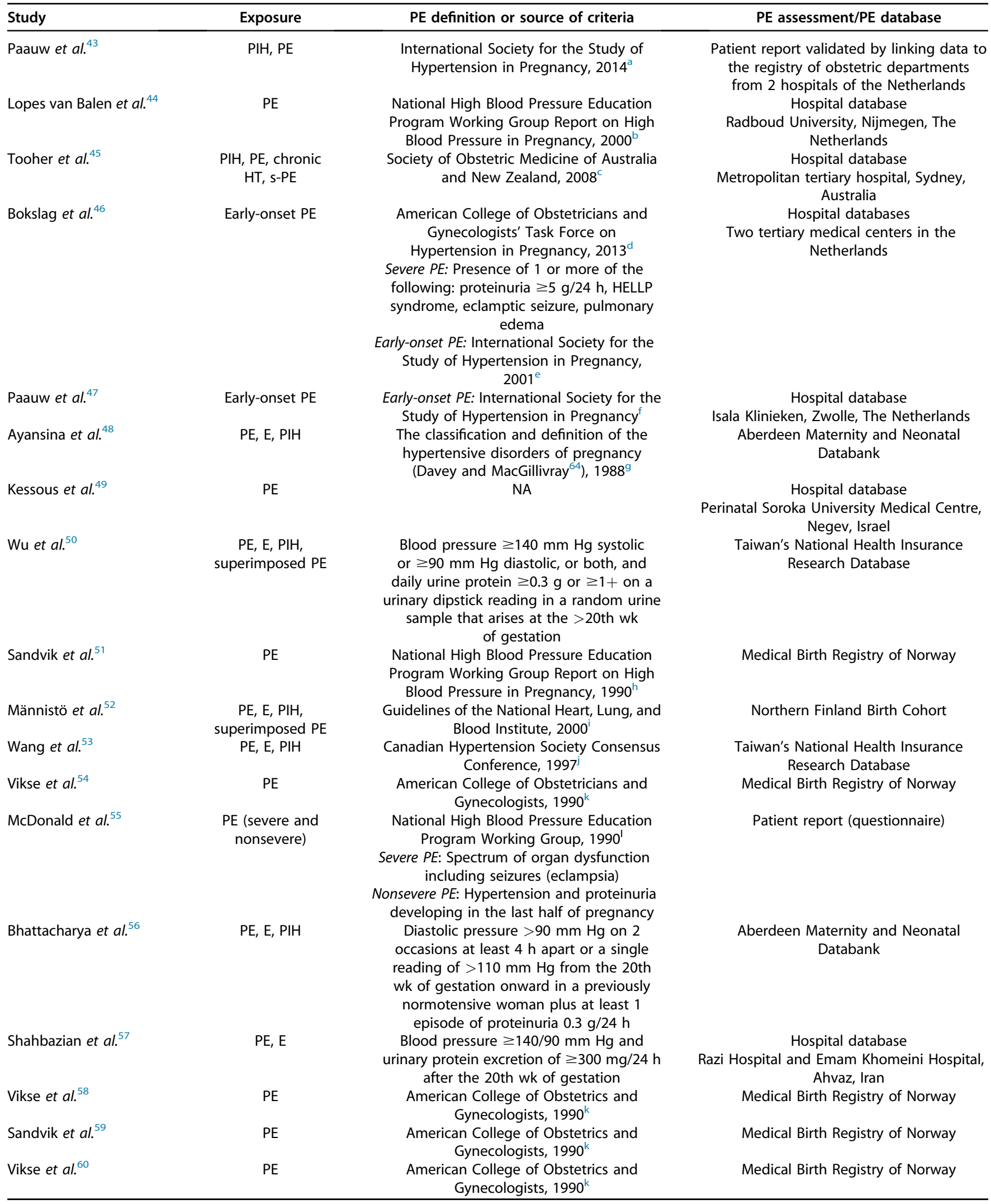


Table 2 | (Continued) Main definitions of exposure in the articles reviewed as well as the source of definition of PE

\begin{tabular}{|c|c|c|c|}
\hline Study & Exposure & PE definition or source of criteria & PE assessment/PE database \\
\hline Lampinen et al. ${ }^{61}$ & PE & NA & $\begin{array}{c}\text { Hospital database } \\
\text { Helsinki University Central, Helsinki, Finland }\end{array}$ \\
\hline Vikse et al. ${ }^{62}$ & PE & $\begin{array}{c}\text { American College of Obstetrics and } \\
\text { Gynecologists, } 1990^{k}\end{array}$ & Medical Birth Registry of Norway \\
\hline Shammas et al. ${ }^{63}$ & PE & NA & $\begin{array}{c}\text { Hospital database } \\
\text { King Hussein Medical Center, Amman, } \\
\text { Jordan }\end{array}$ \\
\hline
\end{tabular}

E, eclampsia; HELLP, hemolysis, elevated liver enzymes, low platelet; HT, hypertension; NA, not available; PE, preeclampsia; PIH, pregnancy-induced hypertension; s-PE, superimposed preeclampsia.

${ }^{a} \mathrm{New}$ onset of hypertension ( $>140 \mathrm{~mm} \mathrm{Hg}$ systolic or $>90 \mathrm{~mm} \mathrm{Hg}$ diastolic) after the 20th wk of gestation and the coexistence of 1 or more of the following new-onset conditions: proteinuria (spot urine protein/creatinine ratio $>30 \mathrm{mg} / \mathrm{mmol}[0.3 \mathrm{mg} / \mathrm{mg}]$ or $>300 \mathrm{mg} / \mathrm{d}$ or at least $1 \mathrm{~g} / \mathrm{L}$ [" $\left.2+{ }^{\prime \prime}\right]$ on dipstick testing); other maternal organ dysfunction (renal insufficiency [creatinine $>90 \mu \mathrm{mol} / \mathrm{l} ; 1.02 \mathrm{mg} / \mathrm{dl}$ ]; liver involvement (elevated transaminases-at least twice the upper limit of normal with or without right upper quadrant or epigastric abdominal pain); neurological complications (examples include eclampsia, altered mental status, blindness, stroke, or more commonly hyperreflexia when accompanied by clonus, severe headaches when accompanied by hyperreflexia, and persistent visual scotomata); hematological complications (thrombocytopenia-platelet count $<150,000 / \mathrm{dl}$, diffuse intravascular coagulation, and hemolysis).

${ }^{b}$ Blood pressure $>140 \mathrm{~mm} \mathrm{Hg}$ systolic or $>90 \mathrm{~mm} \mathrm{Hg}$ diastolic in a woman who was normotensive before the 20th wk of gestation (gestational blood pressure elevation) accompanied by proteinuria. In the absence of proteinuria, the disease is likely to be present when increased blood pressure appears accompanied by any of the following symptoms: headache, blurred vision, and abdominal pain, or by abnormal laboratory test results, specifically low platelet counts and abnormal liver enzyme values. Increase in systolic blood pressure $\geq 140 \mathrm{~mm} \mathrm{Hg}$ or diastolic blood pressure $\geq 90 \mathrm{~mm} \mathrm{Hg}$, or both, after the 20th wk of gestation associated with the involvement of at least 1 other organ manifestation.

${ }^{d}$ Hypertension with 1 or more of the following new-onset conditions: proteinuria, thrombocytopenia, impaired liver function, renal insufficiency, pulmonary edema, or cerebral or visual disturbances.

e Delivery before the 34th wk of gestation, blood pressure $>140 / 90 \mathrm{~mm} \mathrm{Hg}$, and proteinuria $>300 \mathrm{mg} / 24 \mathrm{~h}$.

fDiastolic blood pressure $\geq 90 \mathrm{~mm} \mathrm{Hg}$ with proteinuria ( $\geq 0.3 \mathrm{~g} / 24 \mathrm{~h}$ ) diagnosed between the 20th and 32nd wk of gestation.

${ }^{9}$ Diastolic pressure $>90 \mathrm{~mm} \mathrm{Hg}$ on 2 occasions at least $4 \mathrm{~h}$ apart or a single reading of $>110 \mathrm{~mm} \mathrm{Hg}$; from the 20th wk of gestation onward in a previously normotensive woman plus at least 1 episode of proteinuria of $0.3 \mathrm{~g} / 24 \mathrm{~h}$. Increased BP after the 20th wk of gestation ( $>140 / 90 \mathrm{~mm} \mathrm{Hg}$ ) and proteinuria ( $>0.3 \mathrm{~g}$ in a $24-\mathrm{h}$ urine specimen or $\geq 1+$ on a urinary dipstick reading).

${ }^{\mathrm{h}}$ Women normotensive before the 20 th gestational week but hypertensive (blood pressure $\geq 145 \mathrm{~mm} \mathrm{Hg}$ systolic and $\geq 95 \mathrm{~mm} \mathrm{Hg}$ diastolic) after the 20 th gestational week with proteinuria in $\geq 1$ sample.

iNew-onset hypertension (blood pressure $>140 / 90 \mathrm{~mm} \mathrm{Hg}$ ) with proteinuria of at least $300 \mathrm{mg}$ in a 24-h urine sample after the 20th wk of gestation.

J Increased blood pressure after the 20th wk of gestation (blood pressure $\geq 140 / 90 \mathrm{~mm} \mathrm{Hg}$, or an increase in systolic blood pressure of $\geq 30 \mathrm{~mm}$ Hg or in diastolic blood pressure of $\geq 15 \mathrm{~mm} \mathrm{Hg}$, from measurements before the 20th wk of gestation) and proteinuria ( $\geq 0.3 \mathrm{~g}$ in a $24-\mathrm{h}$ urine specimen or $\geq 1+$ on a urinary dipstick reading).

kPregnancy-induced hypertension with albuminuria, which arises after the 20th wk of gestation.

\section{Meta-analysis: ESRD and albuminuria}

The only outcome found to be significant in the meta-analysis is the risk of ESRD; as the databases are partially overlapping, we included only the largest cohorts (Vikse ${ }^{54}$ and Wang ${ }^{53}$ ) (Figure 2). The risk of ESRD is significantly higher after PE (meta-analytic risk ratio $[\mathrm{RR}], 6.35 ; 95 \%$ confidence interval [CI], 2.73-14.79).

We are uncertain whether there is an increased risk of albuminuria after PE: statistical significance is not reached and CIs are wide, indicating lack of precision in the estimate (meta-analytic RR, 4.31; 95\% CI, 0.95-19.58) (Figure 3); CKD was dichotomized at $60 \mathrm{ml} / \mathrm{min}$ per $1.73 \mathrm{~m}^{2}$ (RR, 2.03; 95\% CI, 0.58-7.32) (excluding 2 studies dealing with hyperfiltration) (Figure 4).

No difference is observed if eGFR is analyzed as a continuous variable (Supplementary Figure S7). The relative risk of hospitalization is also not significantly different (metaanalytic RR, 1.69; 95\% CI, 0.98-2.92) (Supplementary Figure S6).

Stratification for duration of follow-up (dichotomized at 10 years) and region of origin (Europe vs. rest of the world) did not substantially modify results as for ESRD and CKD (Supplementary Figures S8 and S9). Conversely, the exclusion of 1 study (McDonald et al. ${ }^{55}$ ) in the stratification for follow-up, because of the lack of a precise follow-up measure, modifies the RR for albuminuria, whose risk reaches statistical significance (albuminuria: RR, 8.24; 95\% CI, 3.07-22.10). Of note, the excluded study accounted for most of heterogeneity (Supplementary Figures S8A-C and $9 \mathrm{~A}-\mathrm{C})$.

Number of cases that need to be followed up over time to identify an adverse long-term event. In the case of ESRD, the cumulative estimate of the number of cases needed to detect 1 adverse event (calculated as "number needed to treat" [NNT]) was 310 (95\% CI, 120-959). The cumulative prevalence of ESRD was $0.06 \%$, in keeping with a prevalence of ESRD of $\sim 0.1 \%$ in the overall population (this population consists of relatively young women with a lower incidence of ESRD).

The calculations of the NNT lead to 4 for albuminuria and 157 for CKD (CIs were not calculated because the metaanalytic RRs do not reach statistical significance). However, because the crude prevalence of CKD in the control population was only $0.64 \%$, which is remarkably lower than the prevalence of CKD usually reported (estimated as $\sim 3 \%$ in women of childbearing age), we considered it likely that this figure is overestimated.

\section{DISCUSSION}

$\mathrm{PE}$ is a protean disease, which may exert long-term effects on cardiovascular and kidney health, whose entity is however not completely known. As a consequence, follow-up after a PE episode is not established. ${ }^{1-4,13-23,31-41}$

There are several reasons why the results of the analyses of these long-term health effects are not fully clear: the pathogenesis of PE is only partially understood; the recent trend 
Table 3 Main definition and assessment of biochemical data included in outcomes in studies reporting on kidney function or proteinuria

\begin{tabular}{|c|c|c|c|c|c|}
\hline Study & Renal outcome(s) & CKD-eGFR & $C / D$ & Microalbuminuria & $C / D$ \\
\hline Paauw et al. ${ }^{43}$ & CKD, microalbuminuria & $\begin{array}{c}\text { Crs: Enzymatic method } \\
\text { CysC: Turbidimetric assay eGFR: CKD- } \\
\text { EPI equation, creatinine-cystatin } \\
\text { equation } \\
\text { Threshold: eGFR }<60 \mathrm{ml} / \mathrm{min} \text { per } \\
1.73 \mathrm{~m}^{2}\end{array}$ & $\mathrm{D}$ & $\begin{array}{c}\text { Method: Nephelometry (UAE in } \\
\text { 24-h urine collection) } \\
\text { Threshold: }>30 \mathrm{mg} / \mathrm{d}\end{array}$ & $D$ \\
\hline $\begin{array}{l}\text { Lopes van Balen } \\
\text { et al. }{ }^{44}\end{array}$ & CKD, microalbuminuria & $\begin{array}{c}\text { Crs: Colorimetric enzymatic method } \\
\text { eGFR: CKD-EPI equation } \\
\text { Threshold: None }\end{array}$ & C & $\begin{array}{c}\text { Method: Immunonephelometry } \\
\text { (ACR in 24-h urine collection) } \\
\text { Threshold: None }\end{array}$ & C \\
\hline Bokslag et al. ${ }^{46}$ & CKD, microalbuminuria & $\begin{array}{l}\text { Crs: NA eGFR: NA } \\
\text { Threshold: None }\end{array}$ & C & $\begin{array}{c}\text { Method: NA (ACR in a morning urine } \\
\text { sample) } \\
\text { Threshold: None }\end{array}$ & C \\
\hline Paauw et al. ${ }^{47}$ & CKD, proteinuria & $\begin{array}{l}\text { Crs: Colorimetric enzymatic method } \\
\text { eGFR: CKD-EPI equation and MDRD } \\
\text { study equation } \\
\text { Threshold: eGFR }<60 \mathrm{ml} / \mathrm{min} \text { per } \\
1.73 \mathrm{~m}^{2}\end{array}$ & $C, D$ & $\begin{array}{l}\text { Method: Turbidimetric method } \\
\text { (protein/creatinine ratio) } \\
\text { Threshold: }>30 \mathrm{mg} / \mathrm{mmol}\end{array}$ & D \\
\hline Ayansina et al. ${ }^{48}$ & CKD & $\begin{array}{c}\text { Crs: Colorimetric method } \\
\text { eGFR: MDRD study equation } \\
\text { Threshold: eGFR }<60 \mathrm{ml} / \mathrm{min} \text { per } 1.73 \\
\mathrm{~m}^{2}(\geq 90 \mathrm{~d})\end{array}$ & $\mathrm{D}$ & NA & \\
\hline $\begin{array}{l}\text { Männistö } \\
\text { et al. }{ }^{52}\end{array}$ & CKD & $\begin{array}{c}\text { Crs: NA eGFR: NA } \\
\text { Threshold: NA (probably eGFR of } 60 \\
\mathrm{ml} / \mathrm{min} \text { per } 1.73 \mathrm{~m}^{2} \text { ) }\end{array}$ & D & NA & \\
\hline Wang et al. ${ }^{53}$ & CKD & $\begin{array}{c}\text { Crs: NA eGFR: NA } \\
\text { Threshold: NA (probably eGFR of } 60 \\
\mathrm{ml} / \mathrm{min} \text { per } 1.73 \mathrm{~m}^{2} \text { ) }\end{array}$ & $\mathrm{D}$ & NA & \\
\hline $\begin{array}{l}\text { McDonald } \\
\text { et al. }\end{array}$ & CKD, microalbuminuria & $\begin{array}{c}\text { Crs: Colorimetric method eGFR: } \\
\text { MDRD study equation } \\
\text { Threshold: NA (probably eGFR of } 60 \\
\text { ml/min per } 1.73 \mathrm{~m}^{2} \text { ) }\end{array}$ & $C, D$ & $\begin{array}{c}\text { Method: Turbidimetric method (ACR } \\
\text { in a morning urine sample) } \\
\text { Threshold: Microalbuminuria if range } \\
\text { between } 3.4 \text { and } 34.9 \mathrm{mg} / \mathrm{mmol}\end{array}$ & C, D \\
\hline $\begin{array}{l}\text { Shahbazian } \\
\text { et al. }\end{array}$ & CKD, microalbuminuria & $\begin{array}{c}\text { Method: NA mGFR: Creatinine } \\
\text { clearance } \\
\text { Threshold: None }\end{array}$ & C & $\begin{array}{c}\text { Method: NA (ACR in a morning } \\
\text { midstream urine sample) } \\
\text { Threshold: } \geq 30 \mathrm{mg} / \mathrm{mmol}\end{array}$ & $\mathrm{D}$ \\
\hline $\begin{array}{l}\text { Lampinen } \\
\text { et al. }\end{array}$ & CKD, microalbuminuria & $\begin{array}{c}\text { Crs: Colorimetric enzymatic method } \\
\text { eGFR: NA } \\
\text { Threshold: None }\end{array}$ & C & $\begin{array}{l}\text { Method: Immunoturbidimetric } \\
\text { method (UAE in 24-h urine } \\
\text { collection) } \\
\text { Threshold: }>30 \mathrm{mg} / 24 \mathrm{~h}\end{array}$ & C, D \\
\hline $\begin{array}{l}\text { Shammas } \\
\text { et al. }\end{array}$ & CKD, microalbuminuria & $\begin{array}{l}\text { Crs: NA eGFR: NA } \\
\text { Threshold: None }\end{array}$ & C & $\begin{array}{c}\text { Method: NA (UAE in 24-h urine } \\
\text { collection) } \\
\text { Threshold: Excretion of } \\
\text { 20-200 mg/24 h }\end{array}$ & $\mathrm{D}$ \\
\hline Sandvik et al. ${ }^{51}$ & CKD, microalbuminuria & $\begin{array}{c}\text { Crs: Enzymatic method eGFR: } \\
\text { CKD-EPI equation } \\
\text { Threshold for high-normal eGFR: } \\
>114.3 \mathrm{ml} / \mathrm{min} \text { per } 1.73 \mathrm{~m}^{2}\end{array}$ & $\mathrm{D}$ & $\begin{array}{c}\text { Method: Nephelometry (ACR in } 3 \\
\text { morning urine samples) } \\
\text { Threshold: }>2.5 \mathrm{mg} / \mathrm{mmol}\end{array}$ & $\mathrm{D}$ \\
\hline
\end{tabular}

ACR, albumin/creatinine ratio; C, continuous; CKD, chronic kidney disease; CKD-EPI, Chronic Kidney Disease Epidemiology Collaboration; Crs, serum creatinine; CysC, cystatin C; D, dichotomous; eGFR, estimated glomerular filtration rate; MDRD, Modification of Diet in Renal Disease; NA, not available; UAE, urinary albumin excretion.

toward stratification of PE into different categories underlines the heterogeneity of the disease. These include maternal versus placental, severe versus mild, and related versus unrelated derangement of the angiogenic/anti-angiogenic balance. ${ }^{17-22,65,66}$ Furthermore, the relationship between PE and the other hypertensive disorders of pregnancy is complex and one disease may merge with another. ${ }^{65-68}$ Because of changes in definitions and heterogeneity across studies, subtle differences cannot be captured in retrospective analyses (Table 2).

The relationship between CKD and PE is likewise complex and non-univocal: on the one hand, PE may be a cause or a marker of future CKD; on the other hand, there is an increased occurrence of $\mathrm{PE}$ in patients with $\mathrm{CKD}$ and many predisposing factors, including diabetes, obesity, metabolic syndrome, and hypertension, are shared by PE and CKD. ${ }^{34-42,69}$

Available evidence allows us to conclude that there is an increased risk of kidney diseases after PE, but does not permit us to quantify that risk, something which must be done if follow-up strategies are to be defined. What distinguishes our review from the meta-analysis carried out by McDonald et al. is not only the inclusion of recent studies but also the focus on studies that include only medium- to long-term follow-up 
Table 4 | Outcome: risk of ESRD, as reported in the articles reviewed

\begin{tabular}{|c|c|c|c|}
\hline Study & Population & Cumulative incidence & Main results as reported in the articles \\
\hline Paauw et al. ${ }^{43}$ & $\begin{array}{c}\text { Women aged } 28-75 \text { yr with } \\
\text { microalbuminuria who had hypertension in } \\
\text { pregnancy }\end{array}$ & No case & None developed ESRD during follow-up \\
\hline Wang et $a l^{53}$ & $\begin{array}{l}\text { Women in the database of Taiwan's health } \\
\text { care reimbursement claims in the 1996- } \\
2009 \text { period with hypertensive disorders in } \\
\text { first pregnancy who were } 19-40 \text { yr of age } \\
\text { between } 1998 \text { and } 2009\end{array}$ & $\begin{array}{l}\text { Exposed: } 61 / 17,998 \\
\text { Not exposed: } 45 / 213,397\end{array}$ & $\mathrm{HR}, 15.9 ; 95 \% \mathrm{Cl}, 10.8-23.3 ; P<0.001^{\mathrm{a}}$ \\
\hline Vikse et al. ${ }^{54}$ & $\begin{array}{l}\text { All women registered in the Medical Birth } \\
\text { Registry of Norway with a first birth in } \\
\text { 1967-2008 period }\end{array}$ & $\begin{array}{c}\text { First pregnancy: } \\
\text { Exposed: } 52 / 25,821^{\mathrm{b}} \\
\text { Not exposed: } 222 / 503,583 \\
\text { Second pregnancy: Without } \\
\text { children with PE } \\
\text { Exposed: } 39 / 8977^{\mathrm{b}} \\
\text { Not exposed: } 340 / 277,233\end{array}$ & $\begin{array}{c}\text { First pregnancy: } \\
\text { Without siblings with PE: RR, 5.95; } 95 \% \mathrm{Cl} \text {, } \\
4.37-8.11 \\
\text { With siblings with PE: } \mathrm{RR}, 2.76 ; 95 \% \mathrm{Cl} \text {, } \\
0.88-8.63 \\
\text { Second pregnancy: } \\
\text { Without children with PE: RR, 3.81; } 95 \% \mathrm{Cl} \text {, } \\
2.67-5.43 \\
\text { With children with PE: RR, } 2.97 ; 95 \% \mathrm{Cl} \text {, } \\
1.11-7.98\end{array}$ \\
\hline Vikse et al. ${ }^{58}$ & $\begin{array}{l}\text { All women registered in the Norwegian } \\
\text { Kidney Biopsy Registry and Medical Birth } \\
\text { Registry of Norway who, after their last } \\
\text { recorded birth, had a representative kidney } \\
\text { biopsy in 1988-2005 }\end{array}$ & $\begin{array}{l}\text { Exposed: } 10 / 60 \\
\text { Not exposed: NR }\end{array}$ & $\begin{array}{l}\text { First pregnancy: } \mathrm{RR}, 1.2 ; 95 \% \mathrm{Cl}, 0.63-2.4 \text {; } \\
\qquad \begin{array}{c}P=0.5 \\
\text { First or second pregnancy: } \mathrm{RR}, 1.4 ; 95 \% \mathrm{Cl} \text {, } \\
0.77-2.5 ; P=0.3\end{array}\end{array}$ \\
\hline Sandvik et al. ${ }^{59}$ & $\begin{array}{l}\text { Women registered in the Medical Birth } \\
\text { Registry of Norway with a first singleton } \\
\text { delivery between } 1967 \text { and } 1994 \text { with or } \\
\text { without preeclampsia and diabetes } \\
\text { diagnosed before pregnancy }\end{array}$ & $\begin{array}{c}\text { Exposed: } 11 / 216 \\
\text { Not exposed: } 37 / 1265\end{array}$ & $\begin{array}{c}\text { Term birth: RR, } 1.3 ; 95 \% \mathrm{Cl}, 0.41-4.4 \\
\text { Preterm birth: RR, } 2.8 ; 95 \% \mathrm{Cl}, 1.3-6.0\end{array}$ \\
\hline Vikse et al. ${ }^{60}$ & $\begin{array}{l}\text { Women registered in the Medical Birth } \\
\text { Registry of Norway with a first singleton } \\
\text { delivery between } 1967 \text { and } 1991 \text { with or } \\
\text { without PE }\end{array}$ & $\begin{array}{l}\text { Exposed: } 67 / 20,918 \\
\text { Not exposed: } 410 / 549,515\end{array}$ & $\begin{array}{l}\text { After the first pregnancy: } \mathrm{RR}, 4.7 ; 95 \% \mathrm{Cl} \text {, } \\
\qquad 3.6-6.1^{\mathrm{C}}\end{array}$ \\
\hline
\end{tabular}

$\mathrm{Cl}$, confidence interval; $\mathrm{ESRD}$, end-stage renal disease; $\mathrm{HR}$, hazard ratio; $\mathrm{NR}$, not reported; $\mathrm{PE}$, preeclampsia; $\mathrm{RR}$, risk ratio.

${ }^{a}$ Cox proportional hazards method.

bVikse et al:: Cumulative incidence of ESRD in exposed and nonexposed women. Incidence of ESRD according to familial factors: exposed women without siblings with PE, 49/ 22,814; exposed women with siblings with $\mathrm{PE}, 3 / 3007$; exposed women without children with $\mathrm{PE}$, 35/7876; exposed women with children with $\mathrm{PE}$, 4/1101.

${ }^{c} \mathrm{After}$ the second pregnancy (women with $\geq 3$ pregnancies): $\mathrm{PE}$ in first pregnancy only, $\mathrm{RR}, 3.2$ (95\% $\left.\mathrm{Cl}, 2.2-4.9\right)$; $\mathrm{PE}$ in second pregnancy only, $\mathrm{RR}, 6.7$ (95\% $\mathrm{Cl}$, $\left.4.3-10.6\right)$; $\mathrm{PE}$ in both pregnancies, RR, $6.4(95 \% \mathrm{Cl}, 3.0-13.5)$. After third pregnancy (women with $\geq 3$ pregnancies): $\mathrm{PE}$ in first pregnancy only, RR, 14.4 (95\% Cl, 9.4-20.5); PE in second pregnancy only, RR, $7.3(95 \% \mathrm{Cl}, 3.0-18.1)$; $\mathrm{PE}$ in third pregnancy only, RR, 14.3 (95\% Cl, 8.2-24.7); PE in $\geq 2$ pregnancies, $\mathrm{RR}, 15.5$ (95\% Cl, 7.8-30.8).

(at least 4 years, instead of at least 6 weeks postpartum). ${ }^{42}$ The clinical and statistical heterogeneity of the studies examined is high, even with our narrower selection criteria; as a consequence, it was not possible to stratify data as for presence and type of maternal disease or characteristics of PE, and this led us to undertake the meta-analysis with a less robust random effects model. ${ }^{43-63}$

The point of follow-up is crucial: taking the renal functional reserve into account, if $\mathrm{PE}$ represents a substantial hit, but one affecting $<50 \%$ of the kidney parenchyma, it is conceivable that CKD will only become clinically detectable after a long interval. In line with this observation, some articles suggested that the risk of ESRD was graduated according to the entity of the "PE hit" and reported it as higher in women who had $>1$ PE episode or who had PE versus gestational hypertension. ${ }^{53,60}$ The lack of homogeneous definitions, however, does not allow stratifications as for number of episodes or severity of PE, suggesting to address this important issue in future research.
Probably because of the high heterogeneity of the available evidence, our study leads to an intriguing result: we found a significant association between PE and ESRD (meta-analytic RR, 6.35; 95\% CI, 2.73-14.79), the most robust but rare outcome (Figures 2 and 3 ). We are uncertain whether there is an increased risk of albuminuria after PE: statistical significance is not reached and CIs are wide, indicating lack of precision in the estimate (metaanalytic RR, 4.31; 95\% CI, 0.95-19.58). Furthermore, we failed to identify a significant relationship with the intermediate phase of kidney disease, that is, CKD (meta-analytic RR, 2.03; 95\% CI, 0.56-7.32) (Figure 3). The reason why only the first (albuminuria) and last (ESRD) phases of CKD are weakly or strongly correlated to previous $\mathrm{PE}$ presumably resides in the limitations of the studies. In fact, the definition of ESRD is univocal; furthermore, ESRD registries are usually complete, and although none of the studies were able to control predialysis excess mortality, this is probably more relevant in elderly patients than in a 


\begin{tabular}{|c|c|c|c|c|c|c|}
\hline Study & Population & CKD results: eGFR $\left(\mathrm{ml} / \mathrm{min}\right.$ per $\left.1.73 \mathrm{~m}^{2}\right)$ & Analysis & \multicolumn{2}{|c|}{ Albuminuria results } & Analysis \\
\hline Paauw et al. ${ }^{43}$ & $\begin{array}{l}\text { Women aged } 28-75 \text { yr with } \\
\text { microalbuminuria who } \\
\text { answered on hypertension in } \\
\text { pregnancy }\end{array}$ & $\begin{array}{c}\text { Exposed: } 88.0 \pm 16.1 \\
\text { Not exposed: } 91.0 \pm 15.3 \\
H R, 1.04 ; 95 \% \mathrm{Cl}, 0.79-1.37 ; P=0.8\end{array}$ & C & \multicolumn{2}{|c|}{$\begin{array}{l}\text { Exposed: } 9.0 \mathrm{mg} / \mathrm{d}(6.2-14.2 \mathrm{mg} / \mathrm{d}) \\
\text { Not exposed: } 8.1 \mathrm{mg} / \mathrm{d}(6.0-13.7 \mathrm{mg} / \mathrm{d}) \\
P=\mathrm{NA}^{\mathrm{a}}\end{array}$} & C \\
\hline Lopes van Balen et al. ${ }^{44}$ & $\begin{array}{l}\text { Women at a single medical } \\
\text { center in the Netherlands }\end{array}$ & $\begin{array}{l}\text { Exposed: } 105 \pm 16 \\
\text { Not exposed: } 98 \pm 14 \\
\quad P=0.55\end{array}$ & C & \multicolumn{2}{|c|}{$\begin{array}{l}\text { Exposed: } 0.5 \mathrm{~g} / \mathrm{mmol}(0.4-1.1 \mathrm{~g} / \mathrm{mmol}) \\
\text { Not exposed: } 0.6 \mathrm{~g} / \mathrm{mmol}(0.3-1.3 \mathrm{~g} / \mathrm{mmol}) \\
P=0.92\end{array}$} & C \\
\hline & & $\begin{array}{c}\text { Exposed: } 0 / 79 \\
\text { Not exposed: } 0 / 49^{\mathrm{b}}\end{array}$ & $\mathrm{D}$ & \multicolumn{2}{|c|}{$\begin{array}{c}\text { Exposed: } 6 / 79 \\
\text { Not exposed: } 0 / 49^{b}\end{array}$} & D \\
\hline Bokslag et $a l^{46}$ & $\begin{array}{l}\text { Women giving birth during } \\
\text { 1998-2005 from obstetrical } \\
\text { databases of } 2 \text { tertiary centers }\end{array}$ & $\begin{array}{l}\text { Exposed: } 90(82-90) \\
\text { Not exposed: } 90(82-90) \\
\quad P=0.805\end{array}$ & C & \multicolumn{2}{|c|}{$\begin{array}{c}\text { Exposed: } 4.4 \mathrm{~g} / \mathrm{mol}(30-7.8 \mathrm{~g} / \mathrm{mol}) \\
\text { Not exposed: } 3.0 \mathrm{~g} / \mathrm{mol}(3.0-3.9 \mathrm{~g} / \mathrm{mol}) \\
P=0.015\end{array}$} & C \\
\hline Shahbazian et al. ${ }^{57}$ & $\begin{array}{l}\text { Primiparous women between } \\
2001 \text { and } 2003\end{array}$ & $\begin{array}{l}\text { Exposed: } 108 \pm 14 \\
\text { Not exposed: } 110 \pm 17 \\
P=0.59\end{array}$ & C & \multicolumn{2}{|c|}{$\begin{array}{c}\text { Exposed: } 7 / 35 \\
\text { Not exposed: } 0 / 35 \\
P<0.01 \text { (data from the table) }\end{array}$} & D \\
\hline \multirow[t]{2}{*}{ Lampinen et al. ${ }^{61}$} & $\begin{array}{l}\text { Women who delivered during } \\
\text { 1996-1998 with 24-h } \\
\text { proteinuria }\end{array}$ & $\begin{array}{cc}\text { dU-prot }<5 \mathrm{~g}: & \mathrm{dU}-\text { prot } \geq 5 \mathrm{~g}: \\
\text { Exposed: } 108(70-126) & \text { Exposed: } \\
& 126(120-132)\end{array}$ & $\mathrm{C}$ & $\begin{array}{l}\text { dU-prot }<5 \text { g Exposed: } \\
5.5 \mathrm{mg} / \mathrm{d}(4-10 \mathrm{mg} / \mathrm{d})\end{array}$ & $\begin{array}{l}\text { dU-prot } \geq 5 \mathrm{~g}: \\
\text { Exposed: } \\
7 \mathrm{mg} / \mathrm{d}(6-13 \\
\mathrm{mg} / \mathrm{d})\end{array}$ & C \\
\hline & & Not exposed: $126(120-150)^{c}$ & & \multicolumn{2}{|c|}{$\begin{array}{l}\text { Not exposed: } 6 \mathrm{mg} / \mathrm{d} \\
(4.5-9 \mathrm{mg} / \mathrm{d})^{\mathrm{c}}\end{array}$} & \\
\hline \multirow[t]{2}{*}{ McDonald et al. $^{55}$} & \multirow[t]{2}{*}{$\begin{array}{l}\text { Women aged } \geq 50 \text { yr with } \\
\text { dysglycemia who had a prior } \\
\text { CVD event with at least } 1 \\
\text { delivery and information } \\
\text { about PE (ORIGIN trial) }\end{array}$} & $\begin{array}{c}\text { Nonsevere PE: } \\
\text { Exposed: } \\
\text { Continuous: } 74.8 \pm 22.2 \\
\text { Dichotomous: } 82 / 359\end{array}$ & $C, D$ & $\begin{array}{l}\text { Nonsevere PE: } \\
\text { Exposed: } \\
\text { Continuous: } 5.8 \pm \\
26.5 \mathrm{mg} / \mathrm{mmol} \\
\text { Dichotomous: } \\
35 / 359\end{array}$ & $\begin{array}{c}\text { Severe PE: } \\
\text { Exposed: } \\
\text { Continuous: } \\
5.6 \pm 17.5 \\
\mathrm{mg} / \mathrm{mmol} \\
\text { Dichotomous: } \\
14 / 108\end{array}$ & $C, D$ \\
\hline & & $\begin{array}{l}\text { Not exposed: } \\
\text { Continuous: } 74.7 \pm 22.2 \\
\text { Dichotomous: } 940 / 3613^{d}\end{array}$ & & \multicolumn{2}{|c|}{$\begin{array}{l}\text { Not exposed: } \\
\text { Continuous: } 74.7 \pm 22.2 \mathrm{mg} / \mathrm{mmol} \\
\text { Dichotomous: } 940 / 3613^{\mathrm{d}}\end{array}$} & \\
\hline Shammas et al. ${ }^{63}$ & $\begin{array}{l}\text { Women who delivered at King } \\
\text { Hussein Medical Center in } 1988 \\
\text { with PE or normal pregnancy }\end{array}$ & $\begin{array}{l}\text { Exposed: } 76 \mathrm{mmol} / \mathrm{l}^{\mathrm{e}} \\
\text { Not exposed: } 77 \mathrm{mmol} / \mathrm{l}^{\mathrm{e}} \\
P=\mathrm{NA}\end{array}$ & C & $\begin{array}{r}\text { Exposed } \\
\text { Not expos } \\
P<0.0001\end{array}$ & $\begin{array}{l}47 \\
/ 46 \\
\text { lated) }\end{array}$ & D \\
\hline Ayansina et al. ${ }^{48}$ & $\begin{array}{l}\text { Primiparous women born on or } \\
\text { before June } 30,1969, \text { with a } \\
\text { singleton first delivery before } \\
\text { June } 30,2008 \text {, beyond } 20 \text { wk of } \\
\text { gestation identified from AMND }\end{array}$ & $\begin{array}{c}\text { Exposed: } 61 / 811 \\
\text { Not exposed: } 405 / 10,457 \\
\text { OR, 2.02; }(95 \% \mathrm{Cl}, 1.53-2.67 ; P<0.001 \\
\text { HR, } 1.70 ; 95 \% \mathrm{Cl}, 1.30-2.23 ; P<0.001\end{array}$ & $\mathrm{D}$ & & & \\
\hline Männistö et al. ${ }^{52}$ & $\begin{array}{c}\text { Women of the Northern Finland } \\
\text { Birth Cohort } 1966 \\
\text { Deliver at }>28 \text { gestational weeks, } \\
\text { birth weight of } \geq 600 \mathrm{~g}\end{array}$ & $\begin{array}{c}\text { Exposed: } 2 / 242 \\
\text { Not exposed: } 73 / 6552 \\
\mathrm{HR}, 0.75 ; 95 \% \mathrm{Cl}, 0.17-3.38 ; P>0.05\end{array}$ & $\mathrm{D}$ & & & \\
\hline Wang et al. ${ }^{53}$ & $\begin{array}{l}\text { Women in the database of } \\
\text { Taiwan's health care } \\
\text { reimbursement claims in the } \\
1996-2009 \text { period who were } \\
19-40 \text { yr between } 1998 \text { and } \\
2009\end{array}$ & $\begin{array}{c}\text { Exposed: } 121 / 26,651 \\
\text { Not exposed: } 90 / 213,397 \\
\text { HR, } 10.8 ; 95 \% \mathrm{Cl}, 8.20-14.2\end{array}$ & $\mathrm{D}$ & & & \\
\hline
\end{tabular}




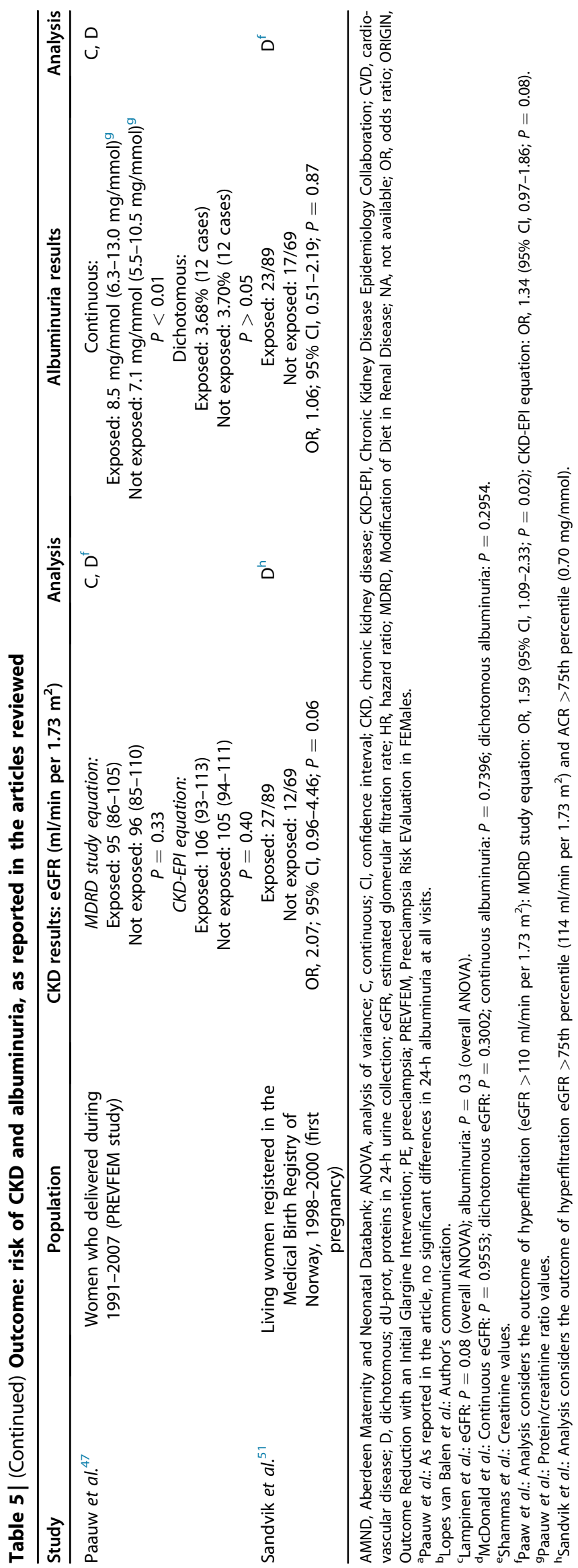

young female population. Albuminuria is more consistently defined in a dichotomous way, and its appearance usually precedes a reduction in kidney function: follow-up may be too short to evidence this decrease, but long enough to make it possible to discover albuminuria. Within the limitations of the studies, the meta-analysis allowed us to establish the number of patients who need to be followed up to detect an adverse long-term event for each outcome (NNT); the number of women who need to be followed up to detect 1 patient with ESRD is high (310; 95\% CI, $120-$ 959). Conversely, if we consider the NNT of 4 in the case of albuminuria, the benefit of organizing regular follow-up is more evident, given the importance of albuminuria as a global marker of cardiovascular health. In both cases, the wide CIs underline that the estimate lacks precision and needs to be refined through further studies. The NNT for ESRD is in line with the figures resulting from screening studies, which are often in the 500 to 2000 range to prevent 1 death over 5 years. ${ }^{70-72}$ However, at difference with these studies in which the detection of a disease (e.g., colon or breast cancer) is rapidly followed by a medical choice, which usually leads to a medical treatment, in the case of ESRD, the detection occurs over a longer period of time, and ESRD represents the final phase of the disease. The lower NNT identified for albuminuria suggests that there may be a space for maneuver for prevention and early treatment, but the current knowledge does not allow further sound inference on the expected benefits (prevention of ESRD).

The interest in this review resides in the updated analysis of the rapidly accumulating evidence on the role of $\mathrm{PE}$ in the development of kidney disease and in the pragmatic evaluation of the organization of further follow-up.

This review has limitations, both because of the methodology chosen and because of the limitations of the literature we were able to retrieve. The review was undertaken with a rapid review of methodology, analyzing the 3 classical databases only-PubMed-MEDLINE, Embase, and Cochrane Library-and focusing on studies with a minimum number of $30 \mathrm{PE}$ cases and a follow-up of at least 4 years, reported in articles published in the new millennium; the hand search was limited to references of review studies, and no search for unpublished data was performed. ${ }^{73-80}$ These choices were made to limit heterogeneity, which we expected and found to be high, and to focus on studies that were likely to be informative for establishing follow-up policies. Conversely, all steps were performed in duplicate and analysis was undertaken in conformity with the Cochrane Collaboration methodology, choosing a random effects model to avoid enhancing the effects observed. ${ }^{81}$

Concerning the limitations of the literature, none of the studies we retrieved was prospective and populations and follow-up were diverse. Further limitations are intrinsic to the study designs: the best population coverage is attained in database linkage studies, whose limitations are those of the original databases; no correction for predialysis mortality was 


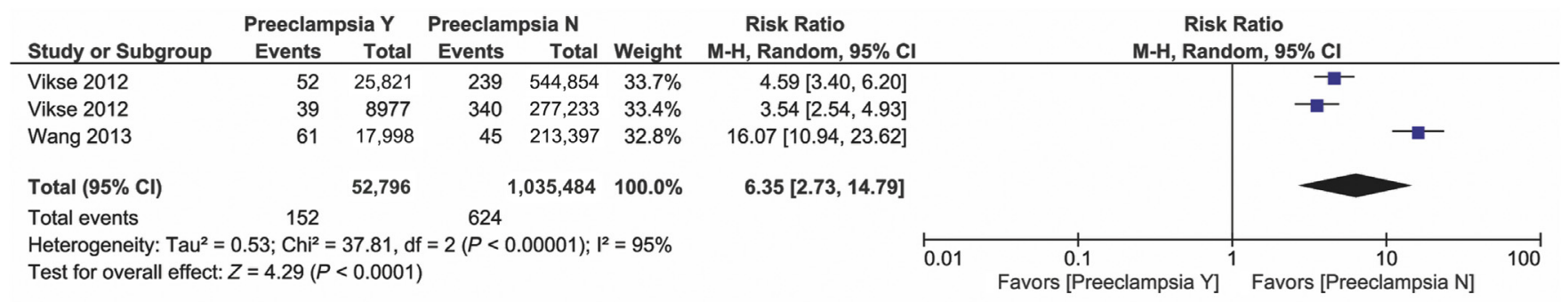

Figure 2| Forest plot for the outcome end-stage renal disease. $\mathrm{Cl}$, confidence interval.

undertaken. The studies of incidence and prevalence of proteinuria and kidney function reduction are more heterogeneous, and the recruitment of the cases for the cross-sectional study is incomplete. Furthermore, evidence comes mainly from Europe (14 of 21 articles) and, although different parts of the world are represented, none of the studies retrieved comes from a low-income country, where the incidence of $\mathrm{CKD}$ is significantly higher and where PE is probably more frequent and more dangerous.

A further limitation, on which we suggest focusing future research, is the lack of uniform information and definition of maternal diseases and of the severity and timing of PE. The heterogeneity of the study designs and outcomes chosen reduced the possibility of performing meta-analyses, and the differences in outcomes are largely unexplained (even after stratification by follow-up times).

These limitations show the need for undertaking prospective cohort studies, which probably represent the only way to define kidney-related risks and to distinguish between the effects of the different facets of PE: revealer of the underlying kidney disease or a hit in the context of a multiplehit pathogenesis. In this regard, follow-up after PE could be a powerful measure to prevent cardiovascular and kidney disease in the long-term.

\section{METHODS}

We followed the Meta-analysis Of Observational Studies in Epidemiology consensus statement for reporting meta-analysis of observational studies (Supplementary Item S1). ${ }^{82}$

We chose the methodology of a rapid review (more focused, essentially exploring the published articles, and limited to 3 main databases with arbitrary but clinically sound limits for the period of the study [2000-2018], number of cases of PE [at least 30], and length of follow-up [at least 4 years]). ${ }^{73-80}$ We empirically chose the cut point of at least 4 years, considering that this could allow detection of CKD (defined as GFR $<60 \mathrm{ml} / \mathrm{min}$ per $1.73 \mathrm{~m}^{2}$ ) in the presence of rapid progression of CKD, defined as loss of $\geq 10 \mathrm{ml} /$ min per $1.73 \mathrm{~m}^{2}$ of GFR per year (from normal GFR, defined as $\geq 90 \mathrm{ml} / \mathrm{min}$ per $1.73 \mathrm{~m}^{2}$ ); furthermore, we considered that the onset of albuminuria was probably antedating the onset of kidney function impairment, and we wanted to leave broad criteria to capture events occurring in the early CKD phases.

No selection for the presence of baseline diseases was made.

Our aim was to obtain timely pragmatic responses to the question of whether the evidence of a negative effect of PE on kidney health is strong enough to lead us to change our clinical practice by organizing structured follow-up programs after a PE episode.

All steps of data selection and extraction were performed in duplicate by a team of 2 nephrologists (GBP and BC), one with a master's degree in systematic reviews. Database search, data selection, and data extraction quality assessment were performed in duplicate by following the classical indications of the Cochrane Handbook versions 5.1 and 5.3. ${ }^{83,84}$ Quality assessment is described in that specific paragraph. Controversies were solved through discussion (EV and GC).

The review was prospectively registered in the PROSPERO database (registration no.: CRD42016043386, dated July 22, 2016).

\section{Eligibility criteria and PICOS criteria}

The eligibility criteria and PICOS criteria are as follows:

$\mathrm{P}$ (patients): women who had $\geq 1$ episodes of $\mathrm{PE}$ during $\geq 1$ pregnancy

$\mathrm{I}$ (intervention - exposure): exposure to $\mathrm{PE}$

$\mathrm{C}$ (controls): women who had at least 1 uncomplicated pregnancy in the same setting and period of time

O (outcomes): long-term (at least 4 years of follow-up) development of CKD (reduction of kidney function and proteinuria), renal-related hospitalization, ESRD, or other relevant kidney healthrelated outcomes

S (studies): observational studies with a control population available, displaying at least 30 cases of PE, with a mean follow-up of at least 4 years, published between 2000 and 2018. No selection for language or quality was performed (see below).

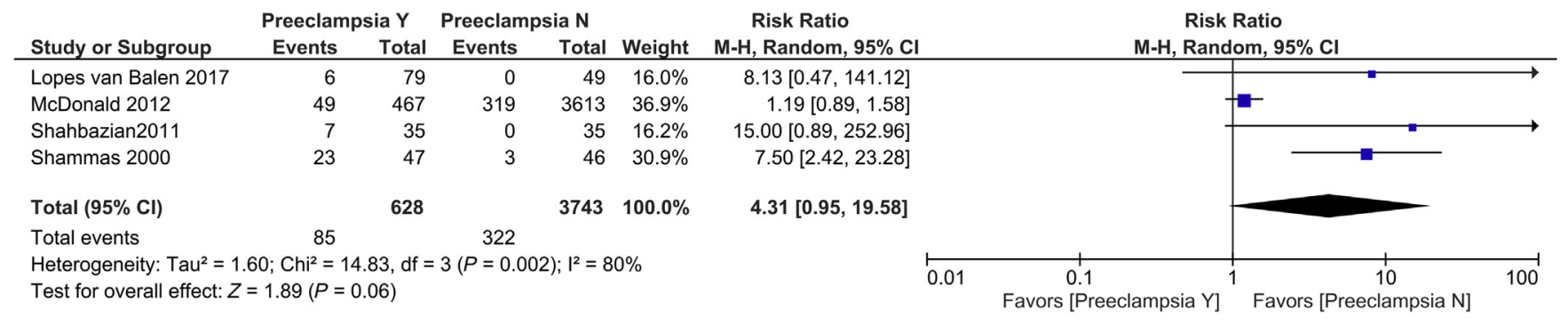

Figure 3 | Forest plot for the outcome albuminuria. $\mathrm{Cl}$, confidence interval. 


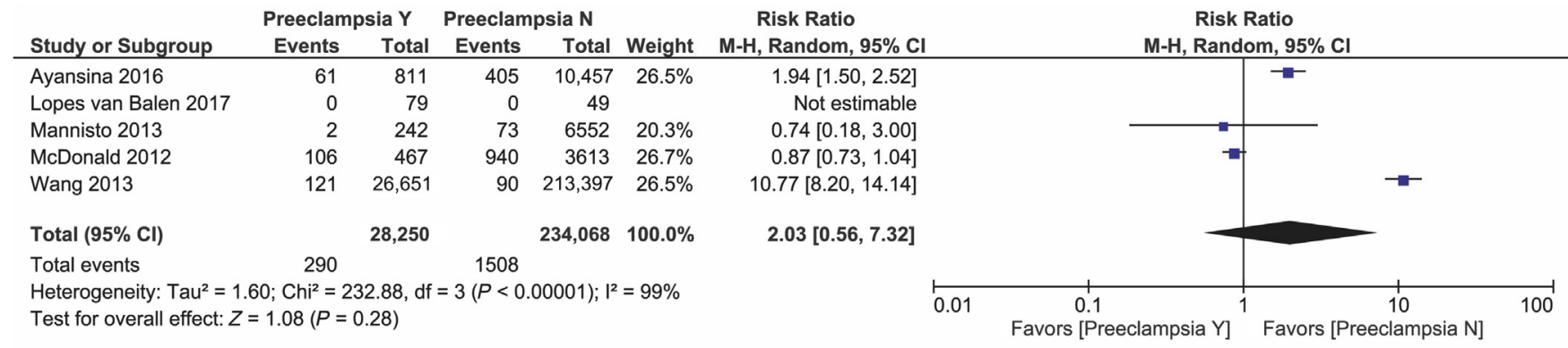

Figure 4 | Forest plot for the outcome chronic kidney disease (dichotomized at estimated glomerular filtration rate of $60 \mathrm{ml} / \mathrm{min}$ per $\left.1.73 \mathrm{~m}^{2}\right)$. $\mathrm{Cl}$, confidence interval.

\section{Search strategy for the identification of studies}

The following databases were searched in duplicate by GBP and BC: MEDLINE, Embase, and Cochrane databases of systematic reviews.

The following terms were used: preeclampsia OR gestosis OR eclampsia OR "hypertensive disorder of pregnancy" OR "hypertensive disorders of pregnancy" OR "pregnancy induced hypertension" OR "pregnancy induced hypertensive disorder" OR "pregnancy induced hypertensive disorders" OR PIH OR HELLP; they were combined with CKD OR "chronic kidney disease" OR dialysis OR hemodialysis OR ESRD OR "end stage kidney disease" OR "end stage renal disease" OR proteinuria OR renal outcome OR renal disease OR kidney disease OR albuminuria OR microalbuminuria.

The period of the search was January 1, 2000, to May 31, 2018.

No language limitation was applied, as the authors as a group understand several European languages, and if needed, they can obtain help for other languages (this did not occur in this review). We reviewed in duplicate reference lists of all studies retrieved in full text; in keeping with rapid review methods, we limited the search of abstracts to those published in the selected databases; in cases where missing or incomplete data would have interfered with metaanalysis, all authors were contacted by $\mathrm{BC}$ via e-mail (twice in the case of no response).

\section{Duplicate publications}

In the case of duplicate or partially duplicate publications (i.e., in the same databases in the case of linkage analysis), we followed the following criteria: for duplicate series, all articles have been included if they deal with different outcomes; in the case of $>1$ article from the same source and on the same outcome, only 1 is included in each meta-analysis; in these cases, either the full article (in the case of abstract and full article) or the most recent article has been chosen.

For partially duplicate publications (same databases, overlapping but nonidentical selections), the largest cohort and, in the case of similar numbers, the most recent one was selected for meta-analysis; all are included in the descriptive analysis and different outcomes are analyzed as previously described.

\section{Data collection and analysis}

We extracted the following information from each study (BC and GBP): population (characteristics of the population, including age, parity, ethnicity, presence or absence of predisposing diseases, such as diabetes or hypertension; inclusion or exclusion of twin pregnancies; and all other relevant information as reported in the articles); number of cases and number of controls; type of study design; aims (as reported in the article); country(ies) where study was performed; period of pregnancy; period of study; follow-up after pregnancy (as reported in the article); type of exposure (PE, hypertensive disorders of pregnancy, and their definitions, whenever available); type of outcomes (definition of all outcomes, including laboratory assessment, if available); type of data analysis; and health outcomes (however defined in the articles; the definitions were also extracted): ESRD, CKD, albuminuria, proteinuria, hospitalization for kidney-related causes, and other relevant outcomes related to CKD (as reported in the articles).

\section{Quality assessment}

Quality of the evidence was assessed by EV and GBP according to the GRADE scale ${ }^{85}$; however, because observational studies are uniformly rated as of low quality by the GRADE scale, the single studies were also was scored by $\mathrm{BC}$ and EV according to the National Institutes of Health criteria. ${ }^{86}$ This latter choice was based on simplicity, reproducibility, and the possibility of giving an overall, individually weighted quality score for each qualitative characteristic of the studies.

Selection on the basis of quality of the study was not performed; however, all the studies are of fair or good quality according to the National Institutes of Health criteria.

\section{Assessment of reporting biases and of heterogeneity}

We assessed publication bias through the funnel plot method for each outcome measure. ${ }^{87}$ Significance was tested as recommended by Higgins and Green. ${ }^{83}$

We performed a test of heterogeneity when $\geq 2$ studies were included in the meta-analysis. We assessed statistically significant heterogeneity between primary outcome studies using the chi-square test and $\mathrm{I}^{2}$ statistic. We considered a significant $\chi^{2}(P<0.01)$ and an $\mathrm{I}^{2}$ value of at least $50 \%$ as statistical heterogeneity. We identified studies that most heavily influenced heterogeneity and performed a sensitivity analysis by omitting them.

\section{Subgroup analyses}

We planned to perform subgroup analyses using the following factors: duration of follow-up, considering the hypothesis that only the longest follow-up would make it possible to detect robust outcomes, such as ESRD; severity, timing of PE, and presence of baseline maternal diseases (superimposed, severe, and early PE could be associated with worse health outcomes); age at pregnancy (older women have a higher risk of both PE and CKD or ESRD); and setting for the analysis. However, either the number of studies making these analyses was too low or data were reported in a highly heterogeneous way, not allowing any sound stratification (as in the case of severity, timing of $\mathrm{PE}$, and presence of maternal diseases). 
Within these limitations, we attempted stratification as for setting of care (Europe vs. other countries) and duration of follow-up (dichotomized at 10 years), acknowledging the clinical importance of these issues.

\section{Data synthesis}

When possible, we combined the outcome measures from the individual studies through meta-analysis; we planned to use a fixed effects model in the case of low heterogeneity and a random effects model in the case of high heterogeneity.

The random effects method incorporates the assumption that different studies estimate different yet related intervention effects. ${ }^{88}$ The method is based on the inverse variance approach, making an adjustment to the study weights according to the extent of variation, or heterogeneity, between the varying intervention effects.

For meta-analysis we used Review Manager (RevMan 5.3). ${ }^{84}$ The forest plot was used to synthesize results. Studies partially or completely answering our PICOS criteria were included in the analysis by using homogeneous measures of effect.

Sensitivity analyses were performed using different effect size measures (e.g., odds ratios and standardized mean differences).

\section{Measures of health effect}

For dichotomous outcomes we calculated RRs and 95\% CIs.

For continuous outcomes we calculated mean difference between groups and $95 \%$ CIs to summarize results across studies.

On the basis of meta-analytic RRs, we estimated the frequency of an event in the PE group and consequently the number of patients with PE who need follow-up to identify an adverse health outcome (corresponding to NNT) and $95 \%$ CIs by using the formulas for NNT. $^{89}$

We performed scenario analysis, testing 2 hypotheses of CKD, one based on the dichotomous data analyzed in the meta-analysis and the other based on the hypothesis that the relationship between cases of ESRD and cases of CKD stages 3-5 not on dialysis was the same as reported in the overall population, with a rounded prevalence of ESRD of $0.1 \%$ versus $5 \%$ in patients with CKD stages 3-5 not on dialysis. ${ }^{69}$ In the case of nonsignificant results, 95\% CIs were omitted in accordance with Altman. ${ }^{89}$

\section{DISCLOSURE}

All the authors declared no competing interests.

\section{ACKNOWLEDGMENTS}

We thank Susan Finnel for her careful language review.

\section{SUPPLEMENTARY MATERIAL}

Figure S1. Funnel plot of comparison: exposed versus not exposed to preeclampsia for the outcome CKD (eGFR $<60 \mathrm{ml} / \mathrm{min}$ per $1.73 \mathrm{~m}^{2}$ ). Figure S2. Funnel plot of comparison: exposed versus not exposed to PE for the outcome CKD (continuous eGFR).

Figure S3. Funnel plot of comparison: exposed versus not exposed to PE for the outcome ESRD.

Figure S4. Funnel plot of comparison: exposed versus not exposed to PE for the outcome albuminuria (dichotomous).

Figure S5. Funnel plot of comparison: exposed versus not exposed to PE for the outcome hospitalization.

Figure S6. Forest plot: exposed versus not exposed to PE for the outcome hospitalization.

Figure S7. Forest plot: exposed vs not exposed to PE for the outcome e-GFR (continuous eGFR).
Figure S8. (A) Forest plot: exposed vs not exposed to PE stratified for duration of follow-up: ESRD. (B) Forest plot: exposed vs not exposed to PE stratified for duration of follow-up: albuminuria. (C) Forest plot: exposed vs not exposed to PE stratified for duration of follow-up: CKD (eGFR $<60 \mathrm{ml} / \mathrm{min}$ per $1.73 \mathrm{~m}^{2}$ ).

Figure S9. (A) Forest plot: exposed vs not exposed to PE stratified for setting of follow-up: ESRD. (B) Forest plot: exposed vs not exposed to PE stratified for setting of follow-up: albuminuria. (C)Forest plot: exposed vs not exposed to PE stratified for setting of follow-up: CKD (eGFR $<60 \mathrm{ml} / \mathrm{min}$ per $1.73 \mathrm{~m}^{2}$ ).

Table S1. Other outcomes, including hospitalization, as reported in the articles.

Table S2. Hospitalization codes considered for analysis.

Table S3A. Inclusion, exclusion criteria, and ratio between "at-risk" and examined cases.

Table S3B. Inclusion, exclusion criteria, and selected cases: retrospective and cross-sectional studies.

Table S3C. Inclusion, exclusion criteria, and selected cases: other study designs.

Table S4. Summary table and quality assessment according to the GRADE evaluation tool.

Table S5. Quality assessment according to the National Institutes of Health evaluation tool.

Supplementary material is linked to the online version of the paper at www.kidney-international.org.

\section{REFERENCES}

1. Phipps E, Prasanna D, Brima W, Jim B. Preeclampsia: updates in pathogenesis, definitions, and guidelines. Clin J Am Soc Nephrol. 2016;11: $1102-1113$.

2. Steegers EA, von Dadelszen P, Duvekot JJ, Pijnenborg P. Pre-eclampsia. Lancet. 2010;376:631-644.

3. Mol BWJ, Roberts CT, Thangaratinam S, et al. Pre-eclampsia. Lancet. 2016;387:999-1011.

4. Umans JG. Obstetric nephrology: preeclampsia-the nephrologist's perspective. Clin J Am Soc Nephrol. 2012;7:2107-2113.

5. Dekker GA. Management of preeclampsia. Pregnancy Hypertens. 2014;4: 246-247.

6. Roberts JM, Mascalzoni D, Ness RB, Poston L, Global Pregnancy Collaboration. Collaboration to understand complex diseases: preeclampsia and adverse pregnancy outcomes. Hypertension. 2016;67: 681-687.

7. Fisher SJ. Why is placentation abnormal in preeclampsia? Am J Obstet Gynecol. 2015;213:S115-S122.

8. Redman C. Pre-eclampsia: a complex and variable disease. Pregnancy Hypertens. 2014;4:241-242.

9. Redman CW, Sargent IL, Staff AC. IFPA Senior Award Lecture: making sense of pre-eclampsia-two placental causes of preeclampsia? Placenta. 2014;35:S20-S25.

10. The American College of Obstetricians and Gynecologists Guidelines and resources: Preeclampsia. Available at: https://www.acog.org/Search? Keyword=preeclampsia\&Categories=ec903560-57a6-46ca-ae6b-62a8 0a257e8d. Accessed June 15, 2019.

11. Redman C. The six stages of pre-eclampsia. Pregnancy Hypertens. 2014;4 246.

12. Myatt L, Roberts JM. Preeclampsia: syndrome or disease? Curr Hypertens Rep. 2015;17:83.

13. Koual M, Abbou H, Carbonnel M, et al. Short-term outcome of patients with preeclampsia. Vasc Health Risk Manag. 2013;9:143-148.

14. Berks D, Steegers EA, Molas M, Visser W. Resolution of hypertension and proteinuria after preeclampsia. Obstet Gynecol. 2009;114:13071314.

15. Ferrazzani S, De Carolis S, Pomini F, et al. The duration of hypertension in the puerperium of preeclamptic women: relationship with renal impairment and week of delivery. Am J Obstet Gynecol. 1994;171:506-512.

16. Remuzzi G, Ruggenenti P. Prevention and treatment of pregnancyassociated hypertension: what have we learned in the last 10 years? Am J Kidney Dis. 1991;18:285-305.

17. Leeman L, Fontaine P. Hypertensive disorders of pregnancy. Am Fam Physician. 2008;78:93-100. 
18. Henry CS, Biedermann SA, Campbell MF, Guntupalli JS. Spectrum of hypertensive emergencies in pregnancy. Crit Care Clin. 2004;20:697-712. ix.

19. Tranquilli AL, Brown MA, Zeeman GG, et al. The definition of severe and early-onset preeclampsia: statements from the International Society for the Study of Hypertension in Pregnancy (ISSHP). Pregnancy Hypertens. 2013;3:44-47.

20. Tranquilli AL. Introduction to ISSHP new classification of preeclampsia. Pregnancy Hypertens. 2013;3:58-59.

21. Folk DM. Hypertensive disorders of pregnancy: overview and current recommendations. J Midwifery Womens Health. 2018;63:289-300.

22. Sutton ALM, Harper LM, Tita ATN. Hypertensive disorders in pregnancy. Obstet Gynecol Clin North Am. 2018;45:333-347.

23. Webster LM, Gill C, Seed PT, et al. Chronic hypertension in pregnancy: the impact of ethnicity and superimposed preeclampsia on placental, endothelial and renal biomarkers. Am J Physiol Regul Integr Comp Physiol. 2018;315:R36-R47.

24. Tan MY, Syngelaki A, Poon LC, et al. Screening for pre-eclampsia by maternal factors and biomarkers at 11-13 weeks' gestation. Ultrasound Obstet Gynecol. 2018;52:186-195.

25. Panaitescu A, Ciobanu A, Syngelaki A, et al. Screening for pre-eclampsia at 35-37 weeks' gestation. Ultrasound Obstet Gynecol. 2018;52: 501-506.

26. Powell KL, Carrozzi A, Stephens AS, et al. Utility of metabolic profiling of serum in the diagnosis of pregnancy complications. Placenta. 2018;66: 65-73.

27. Nair TM. Statistical and artificial neural network-based analysis to understand complexity and heterogeneity in preeclampsia. Comput Biol Chem. 2018;75:222-230.

28. Jelliffe-Pawlowski LL, Rand L, Bedell B, et al. Prediction of preterm birth with and without preeclampsia using mid-pregnancy immune and growth-related molecular factors and maternal characteristics. J Perinatol. 2018;38:963-972.

29. Abdi F, Aghaie Z, Rahnemaie FS, Alimoradi Z. A systematic review of first trimester biochemical and molecular predictive tests for preeclampsia. Curr Hypertens Rev. 2018;14:21-28.

30. Zeisler H, Llurba E, Chantraine F, et al. Predictive value of the sFlt-1:PIGF ratio in women with suspected preeclampsia. N Engl J Med. 2016;374: $13-22$.

31. Cunningham MW Jr, LaMarca B. Risk of cardiovascular disease, end-stage renal disease, and stroke in postpartum women and their fetuses after a hypertensive pregnancy. Am J Physiol Regul Integr Comp Physiol. 2018;315:R521-R528.

32. Scantlebury DC, Kattah AG, Weissgerber $\mathrm{TL}$, et al. Impact of a history of hypertension in pregnancy on later diagnosis of atrial fibrillation. J Am Heart Assoc. 2018;7(10).

33. Perry $\mathrm{H}$, Khalil A, Thilaganathan B. Preeclampsia and the cardiovascular system: an update. Trends Cardiovasc Med. 2018;28:505-513.

34. Pauli JM, Repke JT. Preeclampsia: short-term and long-term implications. Obstet Gynecol Clin North Am. 2015;42:299-313.

35. Rangaswami J, Naranjo M, McCullough PA. Preeclampsia as a form of type 5 cardiorenal syndrome: an underrecognized entity in women's cardiovascular health. Cardiorenal Med. 2018;8:160-172.

36. Piccoli GB, Alrukhaimi M, Liu ZH, et al. World Kidney Day Steering Committee. Women and kidney disease: reflections on World Kidney Day 2018. Kidney Int. 2018;93:278-283.

37. Brown MC, Best KE, Pearce MS, et al. Cardiovascular disease risk in women with pre-eclampsia: systematic review and meta-analysis. Eur J Epidemiol. 2013;28:1-19.

38. Bellamy L, Casas JP, Hingorani AD, Williams DJ. Pre-eclampsia and risk of cardiovascular disease and cancer in later life: systematic review and meta-analysis. BMJ. 2007;335:974.

39. McDonald SD, Malinowski A, Zhou Q, et al. Cardiovascular sequelae of preeclampsia/eclampsia: a systematic review and meta-analyses. Am Heart J. 2008;156:918-930.

40. Ahmed R, Dunford J, Mehran R, et al. Pre-eclampsia and future cardiovascular risk among women: a review. J Am Coll Cardiol. 2014;63: 1815-1822.

41. Wu P, Haththotuwa R, Kwok CS, et al. Preeclampsia and future cardiovascular health: a systematic review and meta-analysis. Circ Cardiovasc Qual Outcomes. 2017;10(2).

42. McDonald SD, Han Z, Walsh MW, et al. Kidney disease after preeclampsia: a systematic review and meta-analysis. Am J Kidney Dis. 2010;55:10261039.
43. Paauw ND, van der Graaf AM, Bozoglan R, et al. Kidney function after a hypertensive disorder of pregnancy: a longitudinal study. Am J Kidney Dis. 2017;71:619-626.

44. Lopes van Balen VA, Spaan JJ, Cornelis T, et al. Endothelial and kidney function in women with a history of preeclampsia and healthy parous controls: a case control study. Microvasc Res. 2017;116:71-76.

45. Tooher J, Thornton C, Makris A, et al. All hypertensive disorders of pregnancy increase the risk of future cardiovascular disease. Hypertension. 2017;70:798-803.

46. Bokslag A, Teunissen PW, Franssen C, et al. Effect of early-onset preeclampsia on cardiovascular risk in the fifth decade of life. Am J Obstet Gynecol. 2017;216:523.e1-523.e7.

47. Paauw ND, Joles JA, Drost JT, et al. High-normal estimated glomerular filtration rate in early-onset preeclamptic women 10 years postpartum. Hypertension. 2016;68:1407-1414.

48. Ayansina D, Black C, Hall SJ, et al. Long term effects of gestational hypertension and pre-eclampsia on kidney function: record linkage study. Pregnancy Hypertens. 2016;6:344-349.

49. Kessous R, Shoham-Vardi I, Pariente G, et al. Long-term maternal atherosclerotic morbidity in women with pre-eclampsia. Heart. 2015;101: 442-446.

50. Wu CC, Chen $\mathrm{SH}, \mathrm{Ho} \mathrm{CH}$, et al. End-stage renal disease after hypertensive disorders in pregnancy. Am J Obstet Gynecol. 2014;210: 147.e1-147.e8.

51. Sandvik MK, Hallan S, Svarstad E, Vikse BE. Preeclampsia and prevalence of microalbuminuria 10 years later. Clin J Am Soc Nephrol. 2013;8: $1126-1134$.

52. Männistö T, Mendola $P$, Vääräsmäki $M$, et al. Elevated blood pressure in pregnancy and subsequent chronic disease risk. Circulation. 2013;127: 681-690.

53. Wang IK, Muo CH, Chang YC, et al. Association between hypertensive disorders during pregnancy and end-stage renal disease: a populationbased study. CMAJ. 2013;185:207-213.

54. Vikse BE, Irgens LM, Karumanchi SA, et al. Familial factors in the association between preeclampsia and later ESRD. Clin J Am Soc Nephrol. 2012;7:1819-1826.

55. McDonald SD, Yusuf S, Walsh MW, et al. Increased cardiovascular risk after pre-eclampsia in women with dysglycaemia. Diabet Med. 2012;30: e1-e7.

56. Bhattacharya S, Prescott GJ, Iversen L, et al. Hypertensive disorders of pregnancy and future health and mortality: a record linkage study. Pregnancy Hypertens. 2011;2:1-7.

57. Shahbazian $\mathrm{N}$, Shahbazian $\mathrm{H}$, Ehsanpour $\mathrm{A}$, et al. Hypertension and microalbuminuria 5 years after pregnancies complicated by preeclampsia. Iran J Kidney Dis. 2011;5:324-327.

58. Vikse BE, Hallan S, Bostad L, et al. Previous preeclampsia and risk for progression of biopsy-verified kidney disease to end-stage renal disease. Nephrol Dial Transplant. 2010;25:3289-3296.

59. Sandvik MK, Iversen BM, Irgens LM, et al. Are adverse pregnancy outcomes risk factors for development of end-stage renal disease in women with diabetes? Nephrol Dial Transplant. 2010;25: 3600-3607.

60. Vikse BE, Irgens LM, Leivestad $\mathrm{T}$, et al. Preeclampsia and the risk of endstage renal disease. N Engl J Med. 2008;359:800-809.

61. Lampinen KH, Rönnback M, Groop PH, Kaaja RJ. Renal and vascular function in women with previous preeclampsia: a comparison of lowand high-degree proteinuria. Kidney Int. 2006;70:1818-1822.

62. Vikse $B E$, Irgens $L M$, Bostad L, Iversen BM. Adverse perinatal outcome and later kidney biopsy in the mother. J Am Soc Nephrol. 2006;17: 837-845.

63. Shammas AG, Maayah JF. Hypertension and its relation to renal function 10 years after pregnancy complicated by pre-eclampsia and pregnancy induced hypertension. Saudi Med J. 2000;21:190-192.

64. Davey DA, MacGillivray I. The classification and definition of the hypertensive disorders of pregnancy. Am J Obstet Gynecol. 1988;158: 892-898.

65. Espinoza J. The need to redefine preeclampsia. Expert Opin Med Diagn. 2012;6:347-357.

66. Malshe AK, Sibai BM. Angiogenic and antiangiogenic markers for prediction and risk classification of preeclampsia. Clin Obstet Gynecol. 2017;60:134-140.

67. Brown MA, Lindheimer MD, de Swiet $M$, et al. The classification and diagnosis of the hypertensive disorders of pregnancy: statement from 
the International Society for the Study of Hypertension in Pregnancy (ISSHP). Hypertens Pregnancy. 2001;20:IX-XIV.

68. Brown MA, Magee LA, Kenny LC, et al. International Society for the Study of Hypertension in Pregnancy (ISSHP). Hypertensive disorders of pregnancy: ISSHP classification, diagnosis, and management recommendations for international practice. Hypertension. 2018;72:24-43.

69. Levey AS, Coresh J. Chronic kidney disease. Lancet. 2012;379:165-180.

70. Rembold CM. Number needed to screen: development of a statistic for disease screening. BMJ. 1998;317:307-312.

71. Fitzpatrick-Lewis D, Ali MU, Warren R, et al. Screening for colorectal cancer: a systematic review and meta-analysis. Clin Colorectal Cancer. 2016;15:298-313.

72. Pinsky PF. Principles of cancer screening. Surg Clin North Am. 2015;95: 953-966.

73. Tricco AC, Antony J, Zarin W, et al. A scoping review of rapid review methods. BMC Med. 2015;13:224.

74. Polisena J, Garritty C, Umscheid CA, et al. Rapid Review Summit: an overview and initiation of a research agenda. Syst Rev. 2015;4:111.

75. Hartling L, Guise JM, Kato E, et al. A taxonomy of rapid reviews links report types and methods to specific decision-making contexts. J Clin Epidemiol. 2015;68:1451-1462.e3.

76. Khangura S, Polisena J, Clifford TJ, et al. Rapid review: an emerging approach to evidence synthesis in health technology assessment. Int J Technol Assess Health Care. 2014;30:20-27.

77. Schünemann HJ, Moja L. Reviews: Rapid! Rapid! Rapid! ... and systematic. Syst Rev. 2015;4:4.

78. Moher D, Stewart L, Shekelle P. All in the family: systematic reviews, rapid reviews, scoping reviews, realist reviews, and more. Syst Rev. 2015;4:183.
79. Kaltenthaler E, Cooper K, Pandor A, et al. The use of rapid review methods in health technology assessments: 3 case studies. BMC Med Res Methodol. 2016;16:108.

80. Plüddemann A, Aronson JK, Onakpoya I, et al. Redefining rapid reviews: a flexible framework for restricted systematic reviews. BMJ Evid Based Med. 2018;23:201-203.

81. Cochrane Community. Available at: https://community.cochrane.org. Accessed June 15, 2019.

82. Stroup DF, Berlin JA, Morton SC, et al. Meta-analysis Of Observational Studies in Epidemiology (MOOSE) Group. Meta-analysis Of Observational Studies in Epidemiology: a proposal for reporting. JAMA. 2000;283: 2008-2012.

83. Higgins JPT, Green S, eds. Cochrane Handbook for Systematic Reviews of Interventions Version 5.1.0 [updated March 2011]. The Cochrane Collaboration, 2011. Available at: www.cochrane-handbook.org. Accessed June 15, 2019.

84. Review Manager (RevMan) [computer program]. Version 5.3. Copenhagen, Denmark: The Nordic Cochrane Centre, The Cochrane Collaboration; 2014

85. Cochrane Community. GRADE approach. Available at: https://training. cochrane.org/grade-approach. Accessed June 15, 2019.

86. National Institutes of Health. National Heart, Lung, and Blood Institute. Study quality assessment tools. Available at: https://www.nhlbi.nih.gov/ health-topics/study-quality-assessment-tools. Accessed June 15, 2019.

87. Sterne JAC, Egger M, Davey Smith G. Investigating and dealing with publication and other biases in meta-analysis. BMJ. 2001;323:101-105.

88. DerSimonian R, Laird N. Meta-analysis in clinical trials. Control Clin Trials. 1986;7:177-188.

89. Altman DG. Confidence intervals for the number needed to treat. BMJ. 1998;317:1309-1312. 